\title{
Natural stand structures, disturbance regimes and successional dynamics in the Eurasian boreal forests: a review with special reference to Russian studies
}

\author{
Ekaterina SHorohova $^{1 *}$, Timo KuUluvainen ${ }^{2}$, Ahto KANGUR $^{3}$, Kalev JõGISTE $^{3}$ \\ ${ }^{1}$ Saint-Petersburg State Forest Academy, 194021 Institutsky str. 5, Saint-Petersburg, Russia \\ ${ }^{2}$ Department of Forest Ecology, P.O. Box 27, FIN-00014, University of Helsinki, Finland \\ ${ }^{3}$ Institute of Forestry and Rural Engineering, Estonian University of Life Sciences, Kreutzwaldi 5, 51014, Tartu, Estonia
}

(Received 8 September 2008; accepted 7 December 2008)

Keywords: stand dynamics / forest-forming process / tree age structure / succession / nature-based management

Mots-clés :

dynamiques forestières / succession forestière / structure d'âge / sylvigénèse / gestion durable

\begin{abstract}
- This review summarizes early stand-scale studies of pristine forest structures, disturbance regimes and successional patterns carried out in boreal Eurasia. We attempt to reveal, characterize and classify stand dynamic types that can be used as templates for nature-based forest management.

- The studies reviewed demonstrate multiple successional pathways in stand development in all types of pristine forests. All-aged stands driven by small-scale disturbances are formed over successional development of several hundreds of years. This endogenous development can be interrupted by standreplacing or partial disturbances leading to successions with even-aged or cohort-structured stands, respectively. In Western Europe, the most common disturbances are windthrows, surface fires and fluctuations in moisture regime; in Eastern Europe and Siberia, the most common disturbances are crown and surface fires and insect outbreaks. Type, return interval and severity of disturbances are strongly influenced by the site conditions and successional stage of a stand.

- Based on characteristics of forest stands and disturbance regime, four main types of pristine boreal forest stand dynamics can be distinguished: (1) even-aged, compositional change dynamics, (2) evenaged, mono-dominant dynamics, (3) cohort dynamics and (4) fine-scale gap dynamics. These types can be mimicked in developing scenarios of ecological sustainable forest management in Eurasian boreal forests.
\end{abstract}

Résumé - Structure des peuplements, régimes de perturbation et dynamiques de succession dans les forêts boréales eurasiennes : une revue basée sur des travaux russes.

- Cette revue bibliographique résume les résultats de nombreuses études anciennes sur la structure des peuplements forestiers, sur les régimes de perturbation et sur les dynamiques de succession en forêt boréale eurasienne. Une typologie des modes de succession est proposée pour servir de cadre à une gestion forestière proche de la nature.

- Les études analysées montrent l'existence de multiples modes de succession et de développement des peuplements dans tous les types de forêts vierges analysées. Des peuplements mélangés comportant des arbres de tous âges se développent en réponse à des perturbations locales avec des dynamiques de plusieurs siècles. Ce développement endogène peut être interrompu par des renouvellements massifs ou des perturbations partielles qui conduisent à des successions basées sur des peuplements équiennes ou structurés en cohortes, respectivement. En Europe occidentale, les perturbations les plus fréquentes sont les chablis, les incendies de surface et des fluctuations des régimes hydriques; en Europe oriental et en Sibérie, ce sont les incendies de surface et de canopée, et les attaques massives par des insectes.

- En se basant sur les caractéristiques des peuplements et des types de perturbations, nous avons pu identifier quatre types principaux de dynamiques forestières : (1) une dynamique de changement de composition spécifique avec une structure équienne ; (2) une dynamique de domination par une espèce avec une structure équienne ; (3) une dynamique de cohortes; et (4) une dynamique de trouées locales. Ces types de succession peuvent servir de base pour le développement de scénarios de gestion forestière durable de ces forêts boréales eurasiennes.

\footnotetext{
*Corresponding author: shorohova@ES13334.spb.edu
} 


\section{INTRODUCTION}

The Eurasian boreal forest belt extends over a huge area from the Russian East to Fennoscandia, covering an area of circa 14 million $\mathrm{km}^{2}$. A major part of the global and Eurasian boreal forest is in Russia, covering an area of circa 9 million $\mathrm{km}^{2}$. The variation of climate, topography and soils shapes the formation of the various ecological communities (Hytteborn et al., 2005; Nikolov and Helmisaari, 1992). The boreal forest is surrounded by thousands of kilometres of ecotones with bordering ecosystems such as tundra, steppe, peatlands, and meadows. Consequently, there is a wide variety of dynamic processes in a constantly changing environment and interactions between forest and other vegetation types. In the present biogeography of the Eurasian boreal forest, one can also find traces of past climate changes having occurred in the late Pleistocene and Holocene, as well as age-old human impact on the forest cover.

Most parts of the Eurasian boreal forest are affected by intensive forest utilization that has fragmented forest landscapes, changed forest structure and modified disturbance regimes (Granström, 2001; Nordlind and Östlund, 2003; Siitonen, 2001). However, in Russia large intact forested areas driven by natural disturbances still exist in remote locations (Yaroshenko et al., 2001). In most of Eurasia, human impact has increased the annually burnt area, despite modern fire prevention methods. In Fennoscandia, the situation is somewhat different due to efficient forest fire supression (FAO, 2007).

Historically, the utilization of forests began as selective cuttings both in Scandinavia and Russia. However, with the development of the forest industry harvesting and management based on clear-cutting was entrenched from the beginning (most parts of Scandinavia) or the mid-20th century (Russia, Finland) in all parts of the Eurasian boreal forest. In Russia, shortcomings of the clear-cutting system were revealed from the very beginning, including low profit due to the unevenaged and uneven-sized structure and low quality of wood in the pristine forests, and the detrimental ecological consequences of massive clear-cuts (Kravchinsky, 1901). As a result, in the 1950s selective cuttings were recommended and new systems of selective cuttings were developed and applied in practice (Tkachenko, 1931; Voropanov, 1950). These cuttings, especially in uneven-aged low-productivity northern forests, were designed by analogy with modern thinnings, aiming at increasing the productivity, resilience and health of forests. The most weakened trees as well as the largest dominant trees that could not increase their increment after improvement in growth conditions were cut. However, in practice the implementation of these selection systems was limited.

In the early 20th century, there was an increased demand for knowledge of the distribution of timber resources as well as the structure of forests to fulfill growing timber consumption (Ilvessalo, 1937). In Scandinavia at that time, the first research steps were taken to describe, classify and understand the structure and development of forests (e.g. Aaltonen, 1919; Arnborg, 1943; Ilvessalo, 1937; Sernander, 1936; Sirén, 1955). In Russia, the theoretical concepts of forest- and soil-forming processes, as well as landscape dynamics, were developed (see review by Utkin, 1999). The first studies on the growth, structure and regeneration of northern forests and attempts at their classifications were conducted by Mal' gin (1842), Vargas de Bedemar (1850), Timofeev (1894), Pole (1906), Bitrikh (1908) and Sokolovsky (1908). Pole (1915) listed 4291 references on forestry, botanical and geographical topics published in northern Russia and Finland. The growth and yield tables for oak (Quercus), pine (Pinus), spruce (Picea) and birch (Betula) forests compiled by Vargas de Bedemar (1850) have not yet lost their importance.

The first empirical findings were mainly static and qualitative descriptions of tree species composition, age structure and diameter distributions (e.g. Kozachenko, 1912; Ivashkevich, 1915). Later the focus was shifted to stand development, and conceptual and quantitative schemes of stand dynamics were constructed, based mostly on the chronosequence approach (Alekseev, 1948; Bogoslovsky, 1921; Ilvessalo, 1937; Sirén, 1955; Voropanov, 1950). More recently, these previous findings and associated systems of classifying stand dynamics were synthesized (Dyrenkov, 1984; Melekhov, 1980).

Currently, the attempts to develop sustainable forest management call for better understanding of natural forest structure and dynamics. Knowledge is needed on central ecological characteristics and processes in the natural forest, such as structure, composition, disturbances, regeneration and successional dynamics (Attiwill, 1994; Kuuluvainen, 2002). For example, the question as to what extent forests are naturally even-aged or uneven-aged has been debated since the 19th century. This issue is related to the type of prevailing disturbance regime, i.e. whether highly severe stand-replacing disturbances or less severe partial disturbances naturally dominate. These issues are important also from the practical point of view. For example, arguments for the natural predominance of stand-replacing disturbances and even-aged stands have been used to legitimatize clear-felling as a natural management system (Sirén, 1955; Valyaev, 1984). On the other hand, where less severe disturbances are the norm and pristine stands are mostly uneven-aged, selective cutting should be promoted if the aim is to maintain the structure and ecological characteristics typical of the forest site type (Dyrenkov and Shergol'd, 1973; Kuuluvainen, 2002; Volkov, 2003).

Differences and similarities in structure and dynamics of Western and Eastern European forest vs. Siberian forest have not been discussed so far. In Russian terminology the taiga forests are classified into two broad types. The so-called dark coniferous taiga consists of Picea abies-dominated forests in Western Europe and poly-dominant Picea abies, P. obovata, Abies sibirica and Pinus sibirica forests in Eastern Europe and Siberia. The so-called light coniferous taiga is composed of Pinus sylvestris and Larix spp.-dominated forests. The number of dominant tree species increases in dark coniferous taiga from West to East.

This review is an attempt to summarize original standscale studies of pristine forest disturbance regimes and successional patterns carried out in boreal Eurasia. A large part of the reviewed studies are written in Russian, and most of them have not been included in earlier reviews (Angelstam, 1998; Angelstam and Kuuluvainen, 2004; Gromtsev, 2002; 
Kuuluvainen, 1994, 2002). The review is also used to synthesize and classify different types of structure and dynamics characteristic of pristine boreal forest stands. We hypothesized that differences in disturbance regimes and site conditions lead to different types of stand structures and dynamics in Eastern Europe and Siberia compared with Western Europe, and in dark-coniferous taiga compared with light-coniferous taiga. Finally, we discuss the implications of this knowledge for ecologically sustainable management. Although the research methods in some of these older Russian and Scandinavian studies on forest structure and development may not meet modern standards, it is believed that the early observations may inspire new research and give answers to topical questions related to the ecology and sustainable management of the boreal forest.

\section{GENERAL CHARACTERISTICS OF EURASIAN BOREAL FOREST ECOSYSTEMS}

\subsection{Climate, soils and tree species}

The climate in boreal Eurasia is characterized by long cold winters and short, rather warm and sunny summers. The mean annual temperature and precipitation are low. However, there is considerable variation, depending on the latitude, maritimecontinentality gradients, and local topography. In continental areas such as central Siberia, winter temperatures fall to $-50{ }^{\circ} \mathrm{C}$; the mean temperature in July varies between $10{ }^{\circ} \mathrm{C}$ and $22{ }^{\circ} \mathrm{C}$; the annual precipitation amounts to between 300 and $600 \mathrm{~mm}$. In the European boreal forest, Atlantic influence and cyclones result in a milder climate with more rain and instability than in the continental regions of Eurasia (Hytteborn et al., 2005).

Soil formation is characterized by the podzolization process: the acidic reaction of decomposing litter causes leaching and moving of minerals in topsoils, resulting in a light horizon below the forest floor (Kaurichev et al., 1989). A fine-grained pattern of lowland forests and wetlands is formed (Hytteborn et al., 2005) where a positive precipitation-evapotranspiration balance, together with low decomposition rates due to low soil temperatures, leads to humus and peat accumulation. In the northernmost areas with the lowest mean annual and winter temperatures, permafrost prevails. Forests can grow where the permafrost melts to a depth of $1 \mathrm{~m}$ during the growing season. The presence of permafrost also leads to the development of palsas and peat plateaus (Bhiry et al., 2007).

The dominant tree species belong to Abies (mainly A. sibirica Ledeb.: Siberian fir), Larix (mainly L. gmelinii (Rupr.) Rupr.: Dahurian larch, L. sibirica Ledeb.: Siberian larch, Picea (mainly P. abies (L.) H. Karst.: Norway spruce, P. obovata Ledeb.: Siberian spruce) and Pinus (mainly P. sylvestris L.: Scots pine, P. sibirica Du Tour or (Loudon) Mayr.: Siberian pine) genera. Deciduous species (Betula pendula Roth.: silver birch, B. pubescens Ehrh.: downy birch, Populus tremula L.: aspen, Alnus incana (L.) Moench.: grey alder, A. glutinosa (L.) Gaertn.: black alder) are represented, particularly after disturbances such as fires or windstorms.
Life history characteristics determine the successional sequence of the tree species at a particular site. The Russian word 'taiga' was first associated with the coniferous forests of Siberia. Today, the word has acquired a more general meaning denoting the coniferous forests of the Northern Hemisphere. Different classifications of vegetation zones describe regional variation, dividing the Boreal Zone latitudinally into subzones and longitudinally into sections. Three vegetation zones (northern, middle and southern) are widely recognized (Ahti et al., 1968). Northernmost forests are composed by Dahurian larch, Siberian spruce and Scots pine. Also hardwoods are represented here: e.g. Betula pubescens ssp. tortuosa. In south of boreal forests, the importance of hardwoods increases, and nemoral species may appear in co-dominance. Boreal forest transition areas are dominated by coniferous species with admixtures of temperate (nemoral) hardwoods, including pedunculate oak Quercus robur L., ash Fraxinus excelsior L., European white-elm Ulmus laevis Pall., Wych elm U. glabra Huds., beech (Fagus sylvatica L.), Norway maple Acer platanoides L., lime Tilia cordata Mill. This zone is the boreonemoral or hemiboreal (Ahti et al., 1968). Ecotones among the northern coniferous forests are detected with mountains or grasslands. In the north the boreal forest undergoes a transition with the tundra vegetation type. The ecotone of the forest-tundra is a belt between the taiga and treeless tundra.

\subsection{Disturbance factors}

Fire has long been acknowledged as a crucial factor shaping boreal forest structure and development (Melekhov, 1947; 1948; Niklasson and Granström, 2000; Saari, 1923; Sirén, 1955). There is wide variability in fire behaviour and regimes, from infrequent high-severity stand-replacing fires to frequent low-severity surface fires. The human impact on fire regimes also differ. Depending on the region, 3-70\% of fires in boreal Eurasia are natural fires, i.e. ignited by lightning (Ivanov, 1996; Gromtsev, 2002).

The 'natural' fire regimes vary in different parts of the Eurasian boreal forest (Buryak et al., 2003; Furyaev, 1996; Gromtsev, 1996; 2002; Sofronov and Volokitina, 1990; Valendik and Ivanova, 2001). It has been estimated that the mean frequency of fires in Russia's European boreal forests vary from 1-2 per century to 1-2 per millennium (Gromtsev, 2002).

The forest fires, burnt areas, and fire hazards of forest stands and landscapes have been classified by Melekhov (1947) and Furyaev (1996). The type of fire, i.e. crown, surface or ground (in peatlands), and its severity are determined by a complex set of factors, including weather conditions (mostly humidity and wind speed), type of forest community (structure, composition and stock of flammable materials), time since and type of previous fire (Furyaev, 1996; Kurbatskij, 1964; Melekhov, 1947). According to Melekhov (1947), surface fires comprises $76-86 \%$, crown fires $16-24 \%$ and ground fires $0.1 \%$ of the total number of fires in the European Russian boreal forest. In Siberia, $87 \%$ of fires are surface, $12 \%$ are crown and $1 \%$ is peatland ground fires (Buryak et al., 2003). 
In Siberian forests, two principal fire regimes were described by Valendik and Ivanova (2001). Low frequencies of fires are characteristic of moist 'dark coniferous' forests dominated by Siberian spruce, Siberian fir and Siberian pine in Western Siberia. In contrast, the high flammability and high frequency of fires are typical for low-mountain 'light coniferous' forests dominated by Scots pine and Siberian larch in Eastern Siberia. Of the total number of fires in Siberia, most $(83 \%)$ occur in Eastern Siberia and the Far East, whereas only $17 \%$ occur in Western Siberia (Valendik and Ivanova, 2001). Gorshkov et al. (2004) detected a dichotomy in the fire disturbance pattern in the Kola Peninsula and Karelia: the fires were either low-severity (less than $33 \%$ of the basal area of the trees killed) or high-severity (over $67 \%$ of the basal area of trees killed).

The concept of 'fire maturity' (Kurbatskij, 1954) deals with the probability that fire emergence gradually increases after snowmelt in the spring or after rainy periods in the summer, associated with the drying of fuels. The fire hazard can be predicted based on the fire maturity characteristics of a forest ecosystem (Furyaev, 1996). Fire maturity refers to a certain moisture level determined by type and stock of fuel and attained after drying for a certain number of days after rain. Fire maturity in the Boreal Zone of European Russia, the Western Siberian Plain and Middle Siberian Plateau, is dependent on forest type, tree species composition and successional stage of a stand, as well as on the landscape type (Kurbatskij, 1964). Burnt forests have been classified according to ecosystem legacies, such as living trees, snags and fallen trees in the northern forests of European Russia (Melekhov, 1948), Siberian pine - broadleaved forests of the Far East (Soloviev and Solodukhin, 1953) and Scots pine and Siberian larch forests in southern Yakutija (Scherbakov and Chugunova, 1960).

In addition to fire, various non-pyrogenic disturbance agents have been recognized as important factors in pristine boreal forests. Wind was demonstrated as a crucial factor shaping the structure and dynamics of the boreal forest (Sernander, 1936; Skvortsova et al., 1983; Turkov, 1985; Ulanova, 2000). The sizes of gaps formed after low- or moderate-severity windthrows can vary from 100 to $10000 \mathrm{~m}^{2}$ (Skvortsova et al., 1983). A dichotomy of the pattern of tree mortality and consequent regeneration recruitment was revealed: either an even or wave-like pattern, depending on disturbance severity (Skvortsova et al., 1983; Pugachevsky, 1992). Polyakov and Semechkin (2004) described cohort-replacing windthrows in Siberian pine stands. Partial mortality of dominant cohorts in the southern boreal spruce forests induced by fluctuation of moisture in the topsoil layer was described by Vygodskaya et al. (2004).

In general, insects, fungal and bacterial diseases have not caused large-scale disturbances in pristine and seminatural European boreal forests (Storozhenko et al., 1992; Storozhenko, 2004), but as 'internal' or chronic disturbance agents they cause formation of gaps (Morozov, 1925; Voropanov, 1950). In contrast, biotic disturbances play an important role in Siberia, often 'substituting' for windthrow as a disturbance agent in late-successional stands. For example, in the Irkutsk region during the period 1870-1963 circa 1, 061 million ha of Siberian pine forests died due to attack by the Siberian silk moth Dendrolimus sibiricus superans. During the last 40 years outbreaks of this pest were registered in the area of 1465000 ha (Vaschuk and Shvidenko, 2006). The main host of this insect is Siberian pine and, to a lesser extent, larch, fir, spruce and pine. The impact of these outbreaks is most severe when followed by fires (Furyaev, 1970), because of high fuel loads of standing dead wood (Verkhunov, 1970).

Other insects able to cause significant forest dieback include dingy larch bell (Zeiraphera diniana), saddleback looper (Ectropis crepuscularia), as well as secondary pests: sixtoothed bark beetle (Ips sexdentatus), eight-toothed bark beetle (I. acuminatus), pine shoot beetle (Tomicus piniperda), lesser pine shoot beetle (Tomicus minor), longhorn beetle (Spondylis buprestoides), great spruce bark beetle (Dendroctonus micans) and Pissodes weevil (Pissodes piniphilus) (Prozorov, 1929).

Gap-phase disturbances caused by death of individual trees or small groups of trees drive the mosaic structure and regeneration dynamics of old-growth forests in the absence of catastrophic disturbances (Hofgaard, 1993; Hytteborn and Packham, 1985; Kuuluvainen et al., 1998; Leemans, 1991; Liu and Hytteborn, 1991; Skvortsova et al., 1983).

\section{CONCEPTUAL, THEORETICAL, AND METHODOLOGICAL ISSUES}

In older literature, many of the views and concepts have a different meaning compared with modern usage. Some phenomena were discussed but were not placed in a theoretical context. For example, the concept of disturbance was not used in the older literature, although the dynamic nature of forests was acknowledged from the very beginning (e.g. Ivashkevich, 1915). Therefore, when referring to the older concepts and terms, we have given their modern interpretation.

Attempts to develop universal scientific theories were typical for the early 20th century. For example, in Finland, the forest site type theory developed by Cajander $(1909 ; 1926)$ has been influential in forest science around the world. This classification system is based on the assumption that competition leads to well-predictable plant community structures determined by the plants' properties and the 'primary' site conditions (Oksanen, 1990). In Russia, the concept of the 'forest-forming process' has been and still is an important and over-arching framework for studies in forest structure and dynamics (Anonymous, 1991; Morozov, 1912, 1925; Utkin, 1999). Studies carried out in the framework describe the interrelationships between forest-forming factors and ecosystem processes and types of stand structures and dynamics.

\subsection{The conceptual framework of the 'forest-forming process' in Russia}

The concept of the "forest-forming process" was introduced by Morozov $(1912 ; 1925)$ and theoretically grounded 


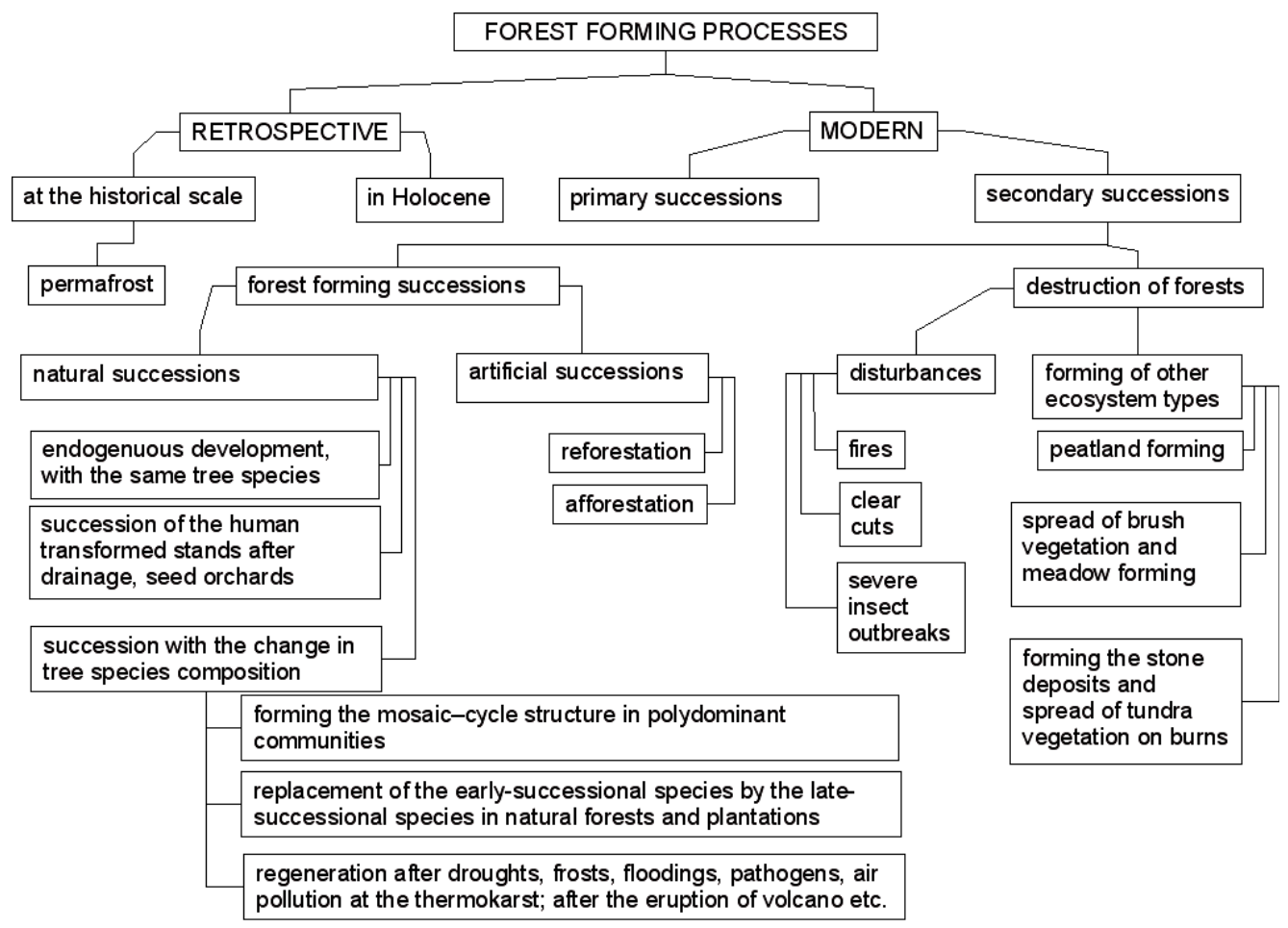

Figure 1. An illustration of the elementary processes that are united by the framework of 'forest-forming process'. Constructed from Utkin (1999) using different approaches for analyzing the forest-forming process: retrospective (biogeography of forests in the Holocene), historical (human impact from ancient times) and modern (current changes in dynamics of forest ecosystems).

by Kolesnikov (1956). Morozov examined the main factors that 'form' forests, i.e. factors that affect forest characteristics and development. He developed a doctrine for species replacement and outlined ways of using the peculiarities of the forest-forming process in the classification of forest vegetation. Morozov $(1912 ; 1925)$ concluded that the main forest-forming factors are: (1) biological characteristics of tree species, (2) factors of the geographic environment (climate, bedrock, relief and soil), (3) the forest plant community itself, or 'biosocial' relationships, (4) the animal community; (5) historical-geological factors and (6) the human impact. He recognized the characteristic features of the process:

- viz. intensity and character of interrelations between tree species in forest communities (competition, mutualism etc.);

- degree of modification of a site by an ecological community (ecological engineering; or reaction according to Clements 1916);

- the degree of 'fitness' of organisms relative to each other and to environmental conditions;

- direction and intensity of natural selection in a community.

Morozov (1912) also suggested an analogy between the forest community and an organism, calling the former a 'social organism'. This idea was analogous to the view of plant communities as 'superorganisms' by Clements $(1904 ; 1916)$. However, in contrast to Clements who believed communities converge through succession from initially distinct, environ- mentally determined starting points towards a climax vegetation, the characteristics of which are solely controlled by the regional climate (the climatic climax), Morozov (1912; 1925) acknowledged the influence of various factors, i.e. the forestforming factors, multiple pathways of succession and continuous change in forest communities.

Kolesnikov (1956) treated the forest-forming process as the totality of all phenomena affecting the characteristics and dynamics of forest communities, including colonization, establishment, growth, die-off and changes in "phytocoenoses" (plant communities). Vegetation and soil development were considered as interacting processes and their changes as thus coinciding. Later Utkin (1991), based on the works of Kolesnikov (1956) and Smolonogov (1968; 1990), suggested different approaches for analyzing the forest-forming process: retrospective (biogeography of forests in the Holocene), historical (human impact from ancient times) and modern (current changes in dynamics of forest ecosystems) (Fig. 1).

Kolesnikov (1956) and Smolonogov (1999) considered forest forming as a cyclic process that consists of a sequence of quantitatively different periods, stages and phases. They believed that each forest community represents a link in the chain of vegetation development at a site. Exogenous factors can influence stage rotation. Severe stand-replacing disturbances, particularly fire and clear-cutting (Sedykh, 1991) and windthrow (Smolonogov, 2000), lead to appearance of secondary communities, including non-forest communities with specific dynamics. Man'ko (1996; 2004), working in 
the Russian Far East, concluded that the stages in a forestforming process are dependent on the characteristics of forest ecosystems, type of exogenous abiotic factors and the impact (severity) of disturbance.

\subsection{Methodological considerations}

Attempts to answer basic questions, and create qualitative descriptions and general theories of phenomena, were typical of the early studies. The outcomes (schemes, general trends, conclusions) were often based more on intuition and extensive field experience, than on empirical data obtained via rigorous sampling procedures as used in modern research. Instead the approach was mainly descriptive. Sampling, if carried out, was mostly subjective and poorly documented.

Many later studies (e.g. in the 1980-1990s) were designed, based on the previously established dominant theoretical frameworks such as the theory of the forest-forming process in Russia and Cajander's theory of forest site types in Finland. These studies provided quantitative descriptions of the structure and dynamics of the boreal forest, based on more rigorous methodologies. For example, in the early Russian studies of uneven-aged stands the size of sample plots was determined in order to measure a minimum of 200 trees of the main 'element of forest', a cohort of trees regenerated within a 40-year period. In practice, this means a sample plot of at least $0.5 \mathrm{ha}$; all trees on the plots were numbered and measured, and statistical parameters were calculated (Dyrenkov, 1984; Kazimirov, 1971; Zyabchenko, 1984).

Most early works on stand development were based on the chronosequence approach, whereas in later research the combination of chronosequence with observations on permanent sample plots, representing only partial substitution of time by space, was applied (Dyrenkov, 1984; Fedorchuk et al., 1998). Despite the shortcomings in research methodology from the modern point of view, the historical studies on structure and dynamics provide an important source of information for generalizing pattern and processes in the boreal forest. This information may also be used to generate hypotheses that can be tested through modern scientific methods. Indeed, this was done to some extent in later publications.

\section{STAND STRUCTURE AND DYNAMICS}

\subsection{Age structure of pristine forest stands}

In Russia, contrasting views of the natural age structure of boreal forest stands have been presented. In the late 19th and early 20th centuries, a general view prevailed that northern forests are naturally even-aged, i.e. stands consist of only one 'element of forest': a single tree age cohort (cf. reviews by Dyrenkov, 1984; Pugachevsky, 1992; Volkov, 2003). However, the opposing view that a pristine forest is naturally unevenaged was also presented at the same time. Bogushevsky (1912) argued that the closer the forest is to its primeval state, the

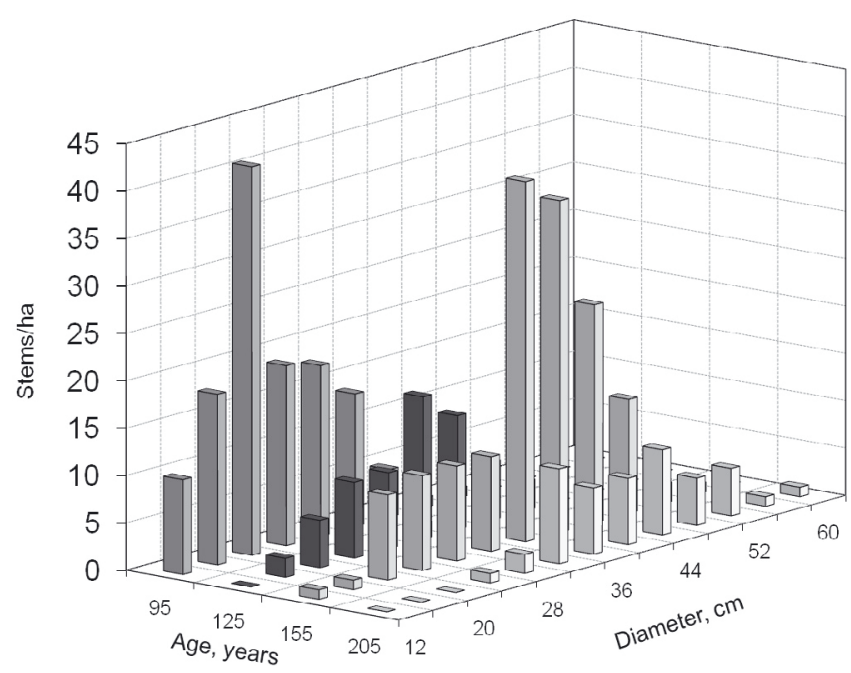

Figure 2. An example of the distribution of trees $\left(\mathrm{ha}^{-1}\right)$ by diameter and age classes in an uneven-aged Norway spruce (Picea abies) forest in the Novgorod region, the southern Boreal Zone (constructed from Kozachenko (1912), sample plot \# 4, on drained loam, average tree height $28 \mathrm{~m}$; trees larger than $8 \mathrm{~cm}$ in $\mathrm{DBH}$ were measured).

more it is a mixture of trees of different age and size; a pristine forest lives, dies and regenerates in small patches.

The first quantitative empirical data documenting the uneven-agedness of pristine forests were presented on the descent of foresters of the Arckangelsk region in 1912. Kozachenko (see Orlov, 1927) presented two-dimensional distributions of tree age and diameter for a Norway spruce forest (Fig. 2). The figure illustrates the general pattern in which the young and small trees are most abundant and the number of trees declines with tree age and size. However, each size class contained trees of various ages.

Ivashkevich (1915) illustrated the structure of a pristine forest with an example of the Siberian pine forest. Unevenagedness together with spatial patchiness were recognized as the main features. This pattern was a consequence of the periodicity of regeneration and the very slow growth of the trees during the first app. 100 years and then growth release due to gap formation. Ivashkevich (1915) discussed the role of natural disturbances (wind, fire or insects) in decreasing the predominance of coniferous trees and converting stands into mixed species stands. This was probably one of the earliest documentations acknowledging the importance of natural disturbances in forest ecosystems (Ivashkevich, 1915).

These early studies and debates about the 'natural' age structure of European boreal forests were synthesized by Orlov (1927), who stated that between the two extremes, even-aged and all-aged forest stands, there is a continuous number of transitions. Orlov indicated that even-aged forests originated either after stand-replacing fires or windthrows. Ivashkevich (1929) drew the same conclusions for forests in the Far East.

In Finland, the studies based on the national Finnish forest inventory data from the early to the mid-20th century point 
out the general uneven-sized character of natural and seminatural stands (Lähde et al., 1991). In Russia, the general dominance of complex structures and uneven-agedness of natural spruce forests was confirmed by Svalov (1961), Valyaev (1961) and Jakovlev (1983). The uneven-aged structure of firdominated forests was demonstrated by Shavnin (1959) and Smolonogov (1960). The structure of uneven-aged Scots pine (Aaltonen, 1919; Buzykin, 1967; Huse, 1964; Shanin, 1967; Verkhunov, 1979), Siberian pine (Povarnitsin, 1944), Siberian larch (Povarnitsin, 1941, 1944; Shanin, 1967) and Korean pine Pinus koraensis (Siebold \& Zucc.) (Moiseenko, 1967) forest stands in Siberia was described in detail. At the same time, Dekatov (1961), Pobedinsky (1961) and Melekhov (1962) recognized the existence of both even-aged and uneven-aged pine forests in the European North. The revealed high variability of pristine boreal forest age structure suggested a need of classification reflecting successional status of stands.

\subsubsection{Classifications of stand structures}

Classifications of pristine forest stand structures are useful in assessing, for example, landscape patterns and proportions of stand successional stages. In Russia, early attempts to classify forest stands by age structure were performed by Sinelschikov (1958) and Gusev (1964). A conference on uneven-aged forests in the Urals, Siberia and Far East, held in Krasnoyarsk in 1967, summed up the attempts at classification of forest stand structures (Anonymous, 1967). The main conclusion of contributing participants of discussion was that the classification should take into account the stand dynamics and conditions that affect formation of the forest structure. This approach was later consolidated by Dyrenkov (1984). The main types of tree age structures based on tree distributions in 40year-wide age cohorts (corresponding to a single "element of forest") were distinguished by Dyrenkov (1984) as follows (Fig. 3):

1. Relatively even-aged stands (from here on referred to as even-aged). The age variation of the overstorey trees does not exceed $40 \mathrm{y}$. The diameter and age distributions are unimodal, and near-normal.

2. Absolutely uneven-aged stands (from here on referred to as all-aged). All 40-year groups of the predominant tree species population up to the lifespan are present, but none exceeds $40 \%$ of the total biomass. The diameter and age distributions are "negative-exponential" or "reverse J-shaped". The following subtypes are distinguished:

2.1 Tree age spatial distribution is even.

2.2 Tree age spatial distribution is patchy.

3. Relatively uneven-aged stands (from here on referred to as uneven-aged). The population of the predominant tree species is continuous up to over $200 \mathrm{y}$, but $50-90 \%$ of the total biomass is concentrated in one of the 40-year-old cohorts. The tree diameter and age distributions are multimodal, i.e. with several peaks. The following subtypes are distinguished:

3.1 Young cohorts predominate; stands regenerate after disturbance.

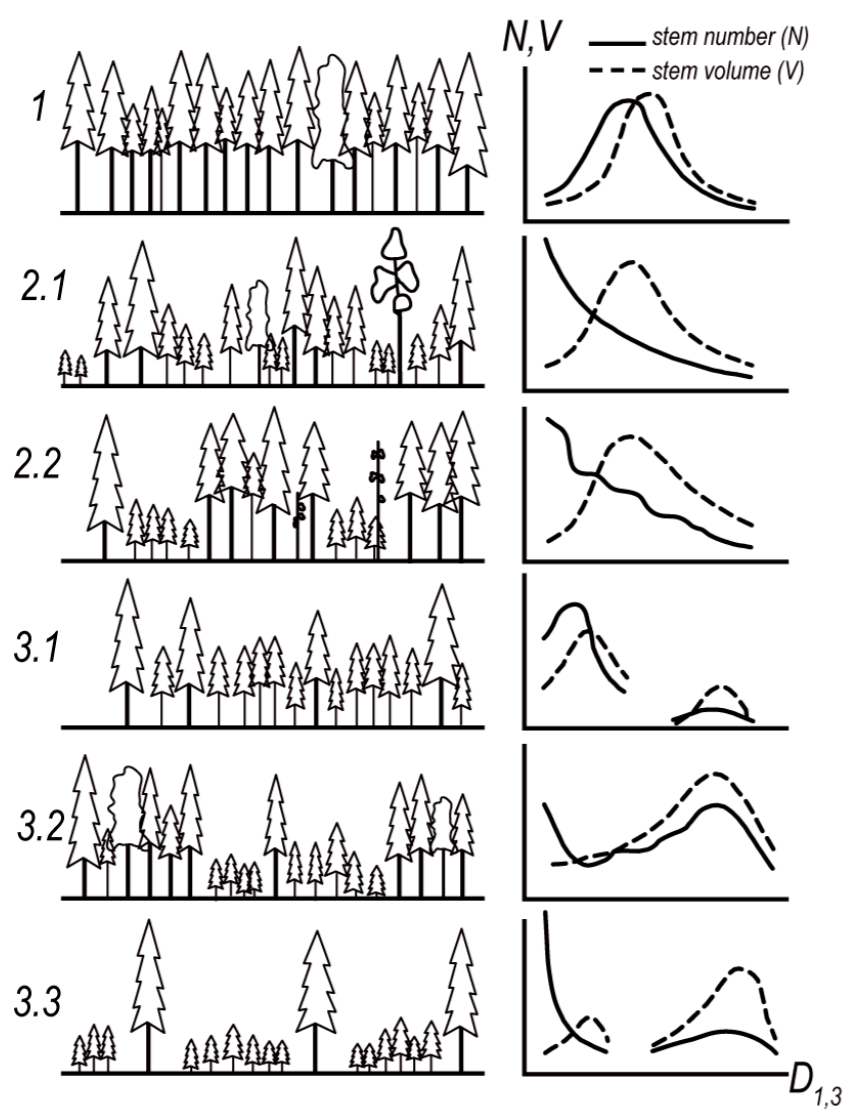

Figure 3. Tree age and diameter distributions in stands with different age structure types (redrawn from Dyrenkov, 1984). 1: Even-aged stands, 2.1: All-aged stands with even distribution of trees, 2.2: Allaged stands with patchy distribution of trees, 3.1: Uneven-aged stands with a dominance of young cohorts, stands regenerated after disturbance, 3.2: Uneven-aged stands with a dominance of old cohorts, process of gradual die-off of the main cohorts, 3.3: Uneven-aged stands with a break in regeneration dynamics.

3.2 Old cohorts predominate; the main cohorts gradually die off.

3.3 Tree age distribution is not continuous; break in regeneration chain.

\subsubsection{Influence of site conditions}

The importance of site conditions and forest stand conditions, such as tree age and diameter distributions, spatial structure and successional pathways, affecting the characteristics of stand structure and dynamics, have been verified in several studies (Dyrenkov, 1984; Korchagin, 1956; Tolmachev, 1954). Dyrenkov (1984) (Fig. 4) showed that all-aged spruce stands could be formed only in the following forest site types: Piceetum myrtillosum (medium moist and fertile sites), $P$. polytrichosum (low fertility, high moisture sites, paludification by groundwater), P. myrtilloso-polytrichosum (transition between the two previous types), $P$. sphagnosum (very 


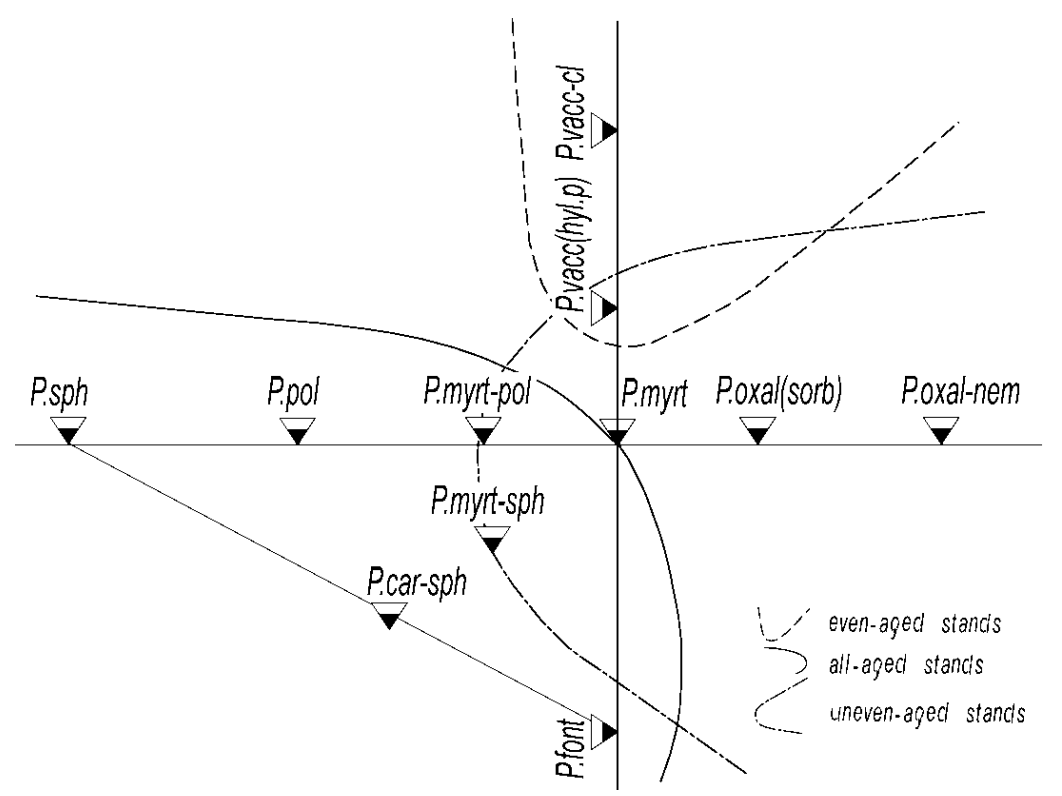

Figure 4. Interrelationship between the main types of tree age structures of pristine spruce stands and forest site types of a plain taiga shown on the 'Sukachev's cross' - a system to classify boreal forest types. The changes on environmental variables on the axes are presented as follows: the crossing of axes refers to average growth conditions on sites; right from crossing is increase in soil moisture, better drainage and soil fertility (from Myrtillus to Oxalis nemoral forest type); left from crossing is increase in soil moisture, but poor drainage and low fertility, paludification (from Myrtillus to Sphagnum forest type); upwards from crossing is decrease in soil moisture and in soil fertility (from Myrtillus to Vaccinium forest type); downwards is increase in soil moisture and paludification by groundwater (from the Myrtillus to fern forest types). The triangles determine the positions of the site types according to the classification. $P$. vacc.-cl.: Piceetum vaccinioso-cladinosum, $P$. vacc. (hyl. p.): $P$. vacciniosum (var. hylocomiosum purum), P. myrt.: P. myrtilloso-hylocomiosum, P. oxal. (sorb.): P. oxalidoso-hylocomiosum (var. sorbosum), P. oxal.-nem.: P. oxalidosum-nemoriherbosum, P. myrt.-pol.: P. myrtilloso-polytrichosum, P. pol.: P. polytrichosum, P. sph.: P. sphagnosum, P. myrt.-sph.: P. myrtilloso-sphagnosum, P. car.-sph.: P. caricoso-sphagnosum, P. font.: P. fontinale. Redrawn from Dyrenkov (1984).

nutrient poor, very moist sites, paludification by precipitation), P. myrtilloso-sphagnosum (transition type), P. caricososphagnosum (nutrient-poor sites, paludification by both precipitation and groundwater) and $P$. fontinale (fertile, moist sites, usually situated near bodies of water). Three forest types, the Myrtillus group viz. Piceetum myrtillosum, P. myrtillosopolytrichosum and P. myrtilloso-sphagnosum, could also form uneven-aged stands. Uneven-aged stands could also be associated with the following forest types: Piceetum oxalidosohylocomiosum (medium to high fertility sites, good moisture regime) and $P$. oxalidoso-nemoriherbosum (the highest fertility in spruce forests, good moisture regime). P. vacciniosum (nutrient-poor sites, dry) and P. vaccinioso-cladinosum (the poorest, very dry sites) could form only even-aged stands due to concurrent surface fires and consequent replacement of spruce by pine (Dyrenkov, 1984).

Abaturov et al. (1988) and Falaleev (1985) documented a variety of types of stand age structure in European and Siberian southern boreal forests. Verkhunov (1970) showed that in Western Siberia and the Baikal region the spatial structure of uneven-aged Scots pine stands depends on site conditions. The stands growing on dry sands and fine sandy loams (e.g. Pinetum lichenosum) have patchy tree age distribution, whereas on fresh sandy and loamy soils (e.g. Pinetum myrtillosum and P. herbosum) the distribution is more even. Ermolenko (1967) associated the age structure of Scots pine forests in the Sayan Mountains with altitude and forest type: the foothill forests (especially of the Pinetum vacciniosum type) are more uneven-aged than the mountain forests.

The variation in tree diameter and age distributions of Norway spruce stands under various site conditions is shown in Figures 5 and 6 (Dyrenkov, 1984). Distinct age cohorts are most pronounced in spruce stands growing either on fertile (Tiliosum, Magnofilicosum) or poor and dry (Vacciniosum) sites. The ages of the oldest spruce cohorts do not exceed 240 years (Dyrenkov, 1984). The stands susceptible to periodic windthrows are those of tall spruce trees with large crowns but shallow root systems. In dry stands, spruce is usually eliminated by low-intensity fires that favor regeneration of pine. Piceetum myrtilloso-polytrichosum, P. myrtillososphagnisum and $P$. myrtillosum sites are characterized by fine-scale gap dynamics and have tree age structure closer to all-aged. Spruce cohorts older than 360 years are present (Fedorchuk et al., 1998; Volkov, 2003).

The studies reviewed demonstrate that the age structure and regeneration dynamics of forests are influenced, among other factors, by site conditions. Pristine forests develop towards an uneven-aged structure, but stand-replacing disturbances can reset them into an even-aged state. Age structure is the first key for understanding stand successional pathways under different disturbance regimes. Even-aged stands are indirect evidence of stand-replacing disturbances. Uneven-aged stands develop 

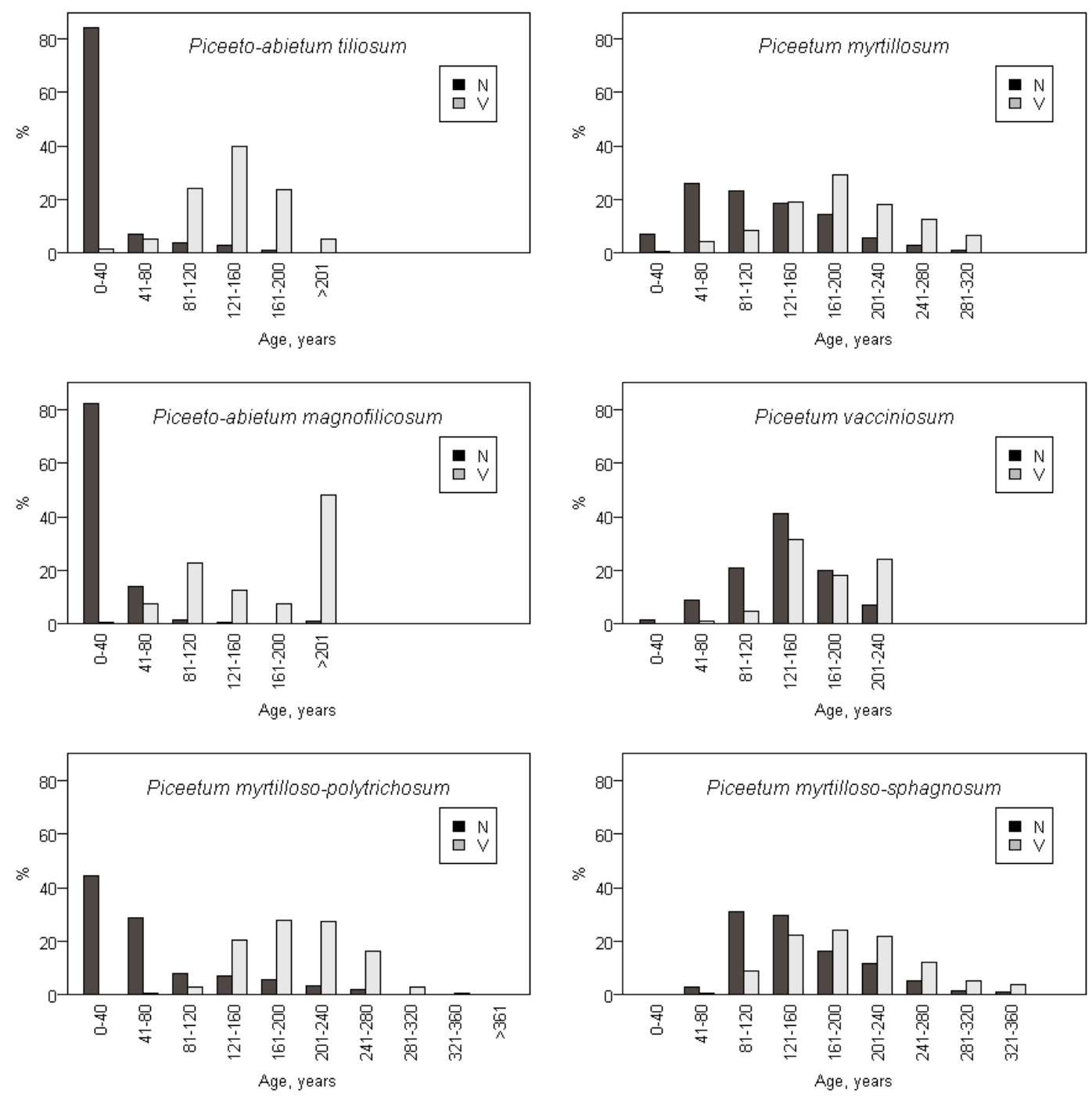

Figure 5. Age structures of pristine boreal spruce stands in different forest types. V: volume, $\mathrm{m}^{3} \mathrm{ha}^{-1}, \mathrm{~N}$ : number of trees per ha. The figures for Piceeto-abietum tiliosum (Middle Prikamye), Piceeto-abietum magnofilicosum (Visherskoye Preduralye), Piceetum myrtilloso-polytrichosum (midriver Vychegda) were constructed from the data of Dyrenkov (1984); those for Piceetum myrtillosum (Karelia) and Piceetum vacciniosum (Karelia) were constructed from the data of Volkov (2003), that for Piceetum myrtilloso-sphagnosum (northeast of the Leningrad region) was constructed from Fedorchuk et al. (1998). See the 'Sukachev's cross' in Figure 4 for ecological characteristics of the forest types.

after partial cohort-replacing disturbances, with the ratio between younger versus older tree cohorts indicating disturbance severity. All-aged stands develop over several centuries of succession in the absence of significant disturbances.

\subsection{Successional pathways of stand development}

\subsubsection{Dark coniferous taiga}

Dark coniferous taiga forests are formed by Norway sprucedominated forests in Western Europe and poly-dominant Norway spruce, Siberian spruce, fir, Siberian pine forests in Eastern Europe and Siberia. In Russia, the first empirical data describing the development of dark coniferous taiga forests were presented in the growth tables complied by Vargas de Bedemar (1850). Bogoslovsky (1921) demonstrated the structure of an uneven-aged Norway spruce forest as a basis for studies on increment and regeneration. The development of spruce forests originating after fires or clear-cuts was quantitatively characterized in the 1960s for many northern regions in growth tables of pure even-aged spruce and pine as well as of mixed spruce-deciduous and deciduous-spruce forests (the former group dominating) (Gorsky, 1962; Ilvessalo, 1967; Kurzin, 1958; Levin and Gusev, 1958; Maksimov, 1967; Ogorodov, 1951).

The motivation for the early studies was often to reveal regularities in forest dynamics that could be used in developing silvicultural practices for timber production (Sirén, 1955; Ilvessalo, 1920; 1970). For this, the central tendency in stand 


\section{Piceetum polytrichosum}
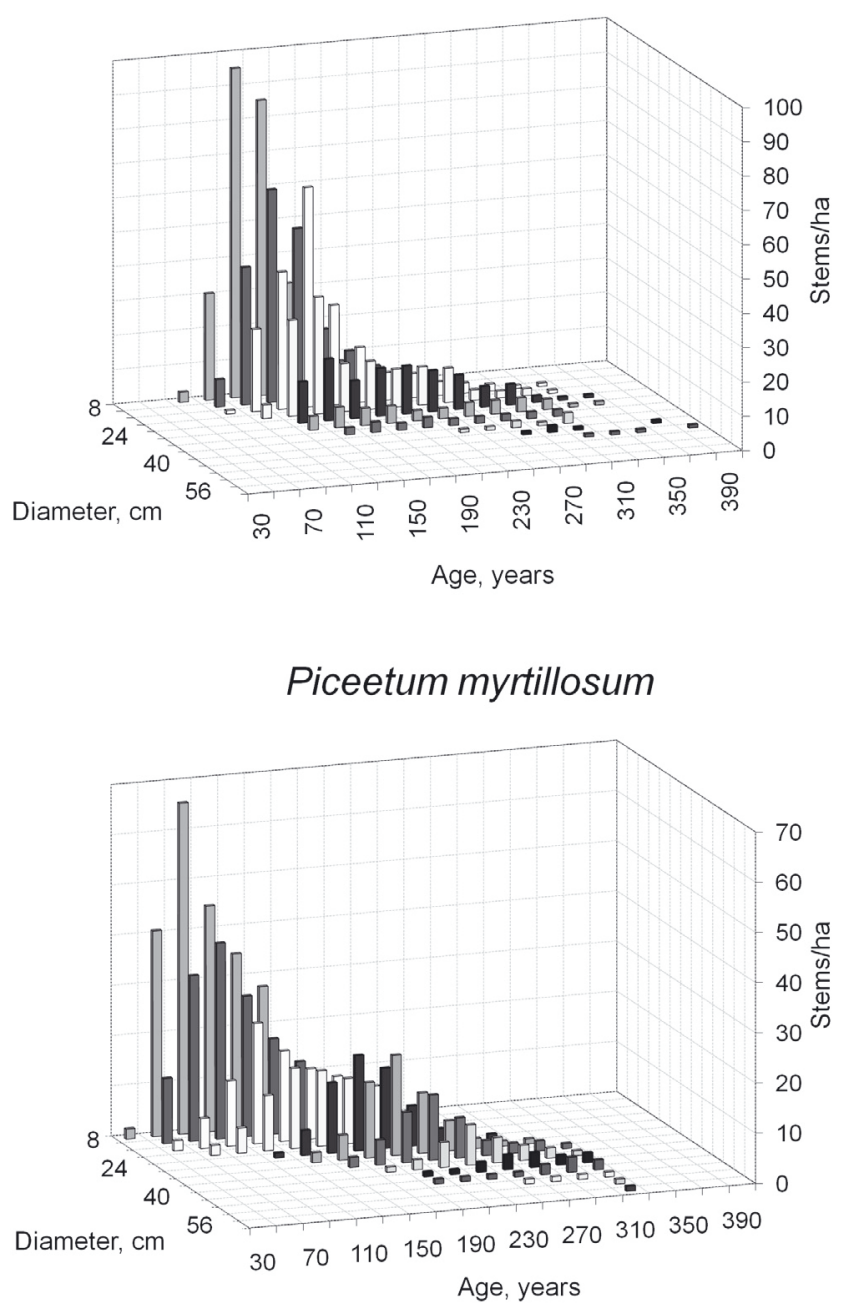

Piceetum vacciniosum

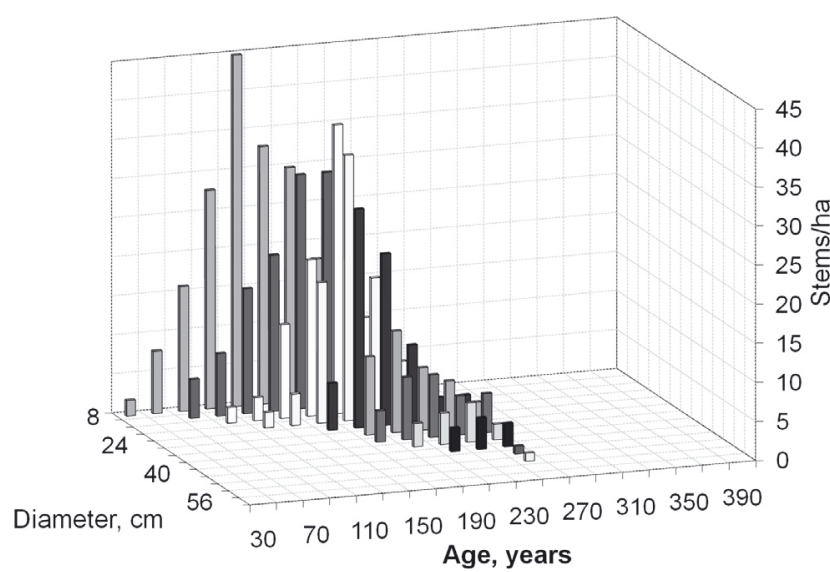

Figure 6. Averaged tree age and diameter distributions for Piceetum polytrichosum, P. myrtillosum and $P$. vacciniosum sites, Karelia (constructed from the data of Volkov, 2003). See the 'Sukachev's cross' on Figure 4 for ecological characteristics of forest types. development rather than its variation was the main interest. A chronosequence approach was used to determine the general developmental patterns and to construct growth tables for even-aged single-species stands, termed 'natural normal' stands. However, such stands were extremely difficult to find (Ilvessalo, 1937). In the 1950s the multiple pathways of forest regeneration and their association with various stand structural types were documented by Voropanov (1950) and Baranov and Grigoriev (1955).

A series of forestry studies traced the successional process leading to an uneven-aged stand structure. Alekseev (1948) published a scheme for the development of northern boreal (Arkhangelsk region) green-moss Norway spruce forests originating after a fire. This scheme suggests that strong competition between spruce and birch is observed in the young and middle-aged stands. By 80 years after the fire, spruce dominance is assured, the birch proportion is circa $30 \%$ and between 60 and 80 years the total mortality constitutes $30 \%$ out of the initial standing volume. At ages of 100-120 years the competition increases and the total mortality amounts to 10.0$11.6 \%$ of the volume; the basal area thus increases. The period of high mortality (14-16\%) begins at 140 years and lasts about 120 years. The basal area constantly decreases (by $56 \%$ from 120 to 240 years). After 240 years the stand die-off (Zerfallphase, according to Leibundgut, 1982) is catastrophically rapid: the mortality amounts to $52 \%$ and the basal area falls significantly. The first generation disappears by 300-320 years after the fire. An uneven-aged stand with an annual volume increment of about $0.25 \%$ gradually forms (Alekseev 1948). Voropanov (1950) presented a similar scheme in more detail and pointed out the time of appearance and dynamics of each generation.

Kazimirov (1971) suggested a similar scheme for endogenous development of Norway spruce forests in Karelia, southern Boreal Zone (Fig. 7), and supplemented it with numerical data on the dynamics of standing volume, density, mean age, diameter, height and volume increment. This scheme shows that the maximum stand volume is reached by circa 140 years, and then decreases until the regeneration of the second post-disturbance cohort. A "stable" (steady state) volume is achieved after 560 years of stand development. The lifetime of cohorts is circa 240 years. The tree number oscillates according to the establishment and die-off processes of the cohorts. Volume increment also oscillates, reaching a maximum at 80 years, collapses then at 220 years, increases again and then gradually stabilizes (Kazimirov, 1971).

In northern Finland, Sirén (1955) studied Norway spruce forests at moist Hylocomium-Myrtillus sites and divided their postfire development into two main stages: "primary", denoting the development after a fire, and "secondary", which is initiated after the "collapse" of the first spruce cohort (Fig. 8). Sirén's (1955) data show a pronounced strong wave-like pattern with a drastic drop of the living stand volume after $300+$ years of succession. It is noteworthy that such a strong wave pattern has not been reported elsewhere (cf. Dyrenkov, 1984). The drastic developmental pattern proposed by Sirén may have been influenced by subjective sampling and the relatively small size of the sample plots (Sirén, 1955; p. 37-39). 


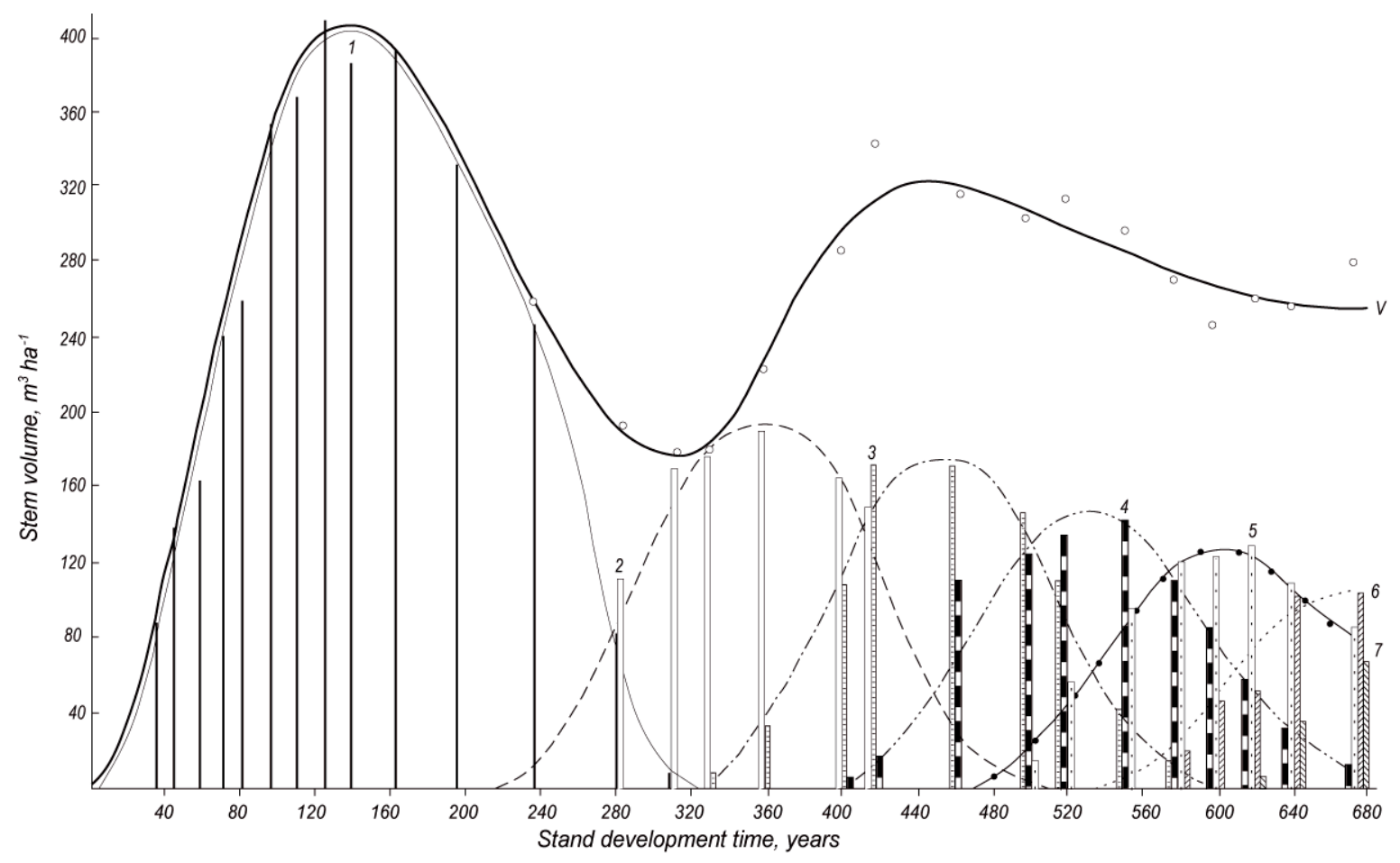

(a)

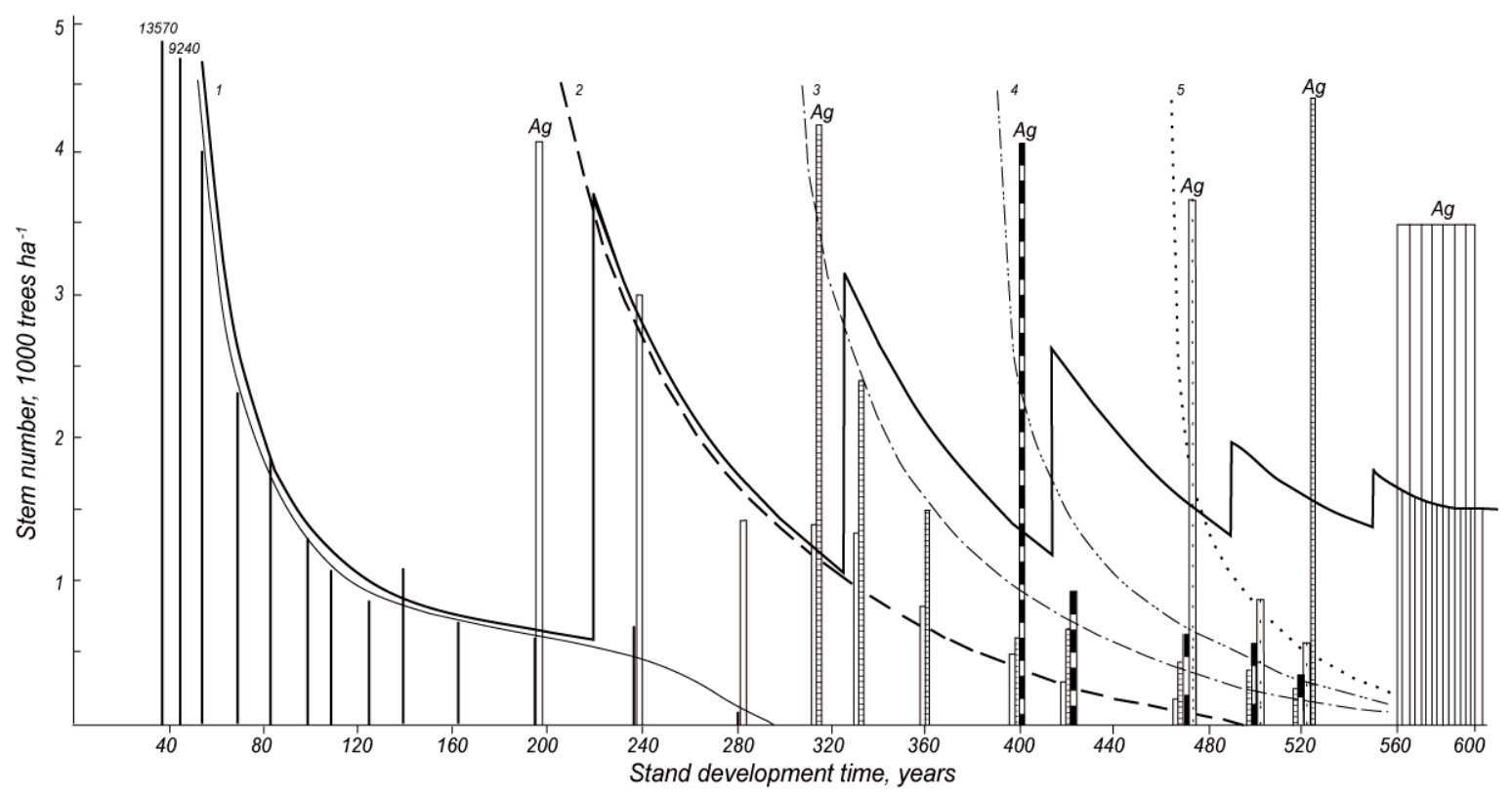

(b)

Figure 7. Dynamics of (a) standing volume, (b) stem number and (c) volume increment of a Norway spruce (Picea abies) stand in Piceetum myrtillosum (medium fertility and moisture) forest type in Karelia (redrawn from Kazimirov, 1971). 1-7: Numbers of cohorts, circles: empirical data from sample plots, solid lines: theoretical curves, Ag: seedlings and undergrowth. 


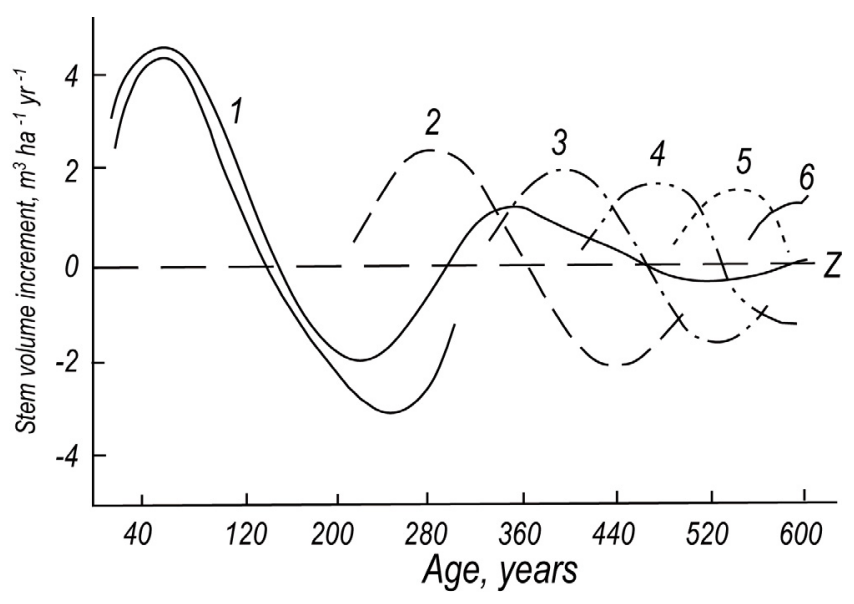

(c)

Figure 7. Continued

In Sirén's (1955) scheme birch is the first dominant in the "primary" succession, but spruce acquires dominance circa 80 years after the fire (Fig. 8). At 240 years after the fire, almost pure spruce stands attain the maximum standing volume of circa $280 \mathrm{~m}^{3} / \mathrm{ha}$. The stand die-off occurs by circa 360 years, leading to natural regeneration of spruce and birch. This is the start of "secondary" succession, according to Sirén (1955), but this time spruce is dominant from the beginning. In 220-240 years a new but lower peak of standing volume is attained at circa $190 \mathrm{~m}^{2} / \mathrm{h}$. The main reason for the declining productivity according to Sirén (1955) is the accumulation of raw humus and the consequent immobilization and slow cycling of nutrients.

In the northern boreal forest in Russia, Dyrenkov (1984) observed a productivity decline in fire-originated spruce forests with successional development, but he stated that it is not a widespread phenomenon. In contrast, he reported stand characteristics in late successional spruce forests to be stable.

Schemes for endogenous development were also constructed for Siberian and Far-Eastern mixed dark coniferous forests. Falaleev (1985) suggested that the dark coniferous Siberian forests gradually pass through a 7 -stage cycle from young to over-mature forest and then final die-off. This endogenous development could be interrupted by humaninduced (clear-cuttings) or natural (fires, insect outbreaks, windthrows etc.) disturbances. Man'ko (1967), in studying the spruce-fir forests in the Far East, distinguished the following developmental phases: (1) maturity, (2) overmaturity of the dominant spruce generation, (3) the temporal dominance of fir and (4) forming the new forest stand dominated by spruce. Komin (1983) and Kozin (1982), working in the Russian Far East, suggested a scheme of cyclic endogenous successional development in uneven-aged virgin forest associated with solar activity. Komin (2003) argued that endogenous development of forest stands requires 1000-1200 years to attain an all-aged state with fine-scale gap dynamics. Most stand development sequences in the Urals and Siberia include tree species replacement (Kataeva and Korzukhin, 1987; Konstantinov and
Gorozhankina, 1995; Smolonogov, 1968; 1990). The schemes of postfire dynamics of Siberian pine forests constructed by Smolonogov et al. (1971), Kostuychenko (1977; see Kataeva and Korzukhin, 1987), Sedykh (1979), Smolonogov (1990), Furyaev (1996) and Pakhuchij (1999) represent successional variants in which shade-tolerant Siberian pine outcompetes the birch, aspen, spruce, and fir, and finally predominates.

Interesting zonal and site-specific peculiarities of postfire dynamics of polydominant dark coniferous forests in the Western Siberian Plain were described by Smolonogov (1990) (Fig. 9). In low-density tree communities in the subtundra, characterized by extremely dry and poor growth conditions (vaccinioso-ledosum type), Siberian pine predominates throughout the 300-350 years of stand development, i.e. until die-off of the first postfire cohort. Siberian pine recruitment is abundant at the initial stages of succession together with silver and downy birch and spruce. In the northern Boreal Zone, birch with an admixture of aspen predominates at the initial stages in the same vaccinioso-ledosum forest type, however, Siberian pine and Scots pine also regenerate. Siberian pine together with other coniferous species acquires dominance by 60-80 years after the fire (Smolonogov, 1990). In the middle Boreal Zone, e.g. in the hylocomiosum forest type with average moisture and productivity, the dominance of birch and aspen lasts until 80 years after the fire. Spruce and fir become dominant 80 years after the fire and remain dominant until 160 years after the fire. Increased mortality of the first postfire cohorts of fir and abundant recruitment of the next cohorts of Siberian pine, spruce and fir begin from 160 years and last until 400 years after the fire.

Under optimal conditions in the southern Boreal Zone (e.g. hylocomiosum forest type, average moisture and productivity) the dominance of deciduous tree species lasts approximately 100 years, after which spruce predominates until 180 years with a high proportion of fir. The period 180-400 years after the fire is characterized by the dominant role of Siberian pine with a high admixture of spruce and fir at the beginning and their dominance at the end of the period. All the species form several cohorts during succession. Siberian pine under these optimal conditions rarely forms the next postfire cohorts, which can be explained by its sometimes low seed production, rodents feeding on seeds, intense competition with spruce and fir, as well as by vigorous grass cover in gaps. The dynamics of dark coniferous forests on gleysols (filipendulosoequisetosum, equisetoso-fruticuloso-sphagnosum forest types) is different. These forests burn very seldom; consequently it is almost impossible to find stands younger than 80 years. All processes are gradual. Birch can predominate until 100 years but does not form a separate layer. Siberian pine forms several cohorts, while the percentage of spruce, fir and pine is stable throughout succession (Smolonogov, 1990).

Dyrenkov (1984) suggested five main types of Eurasian boreal spruce forest dynamics. The first dynamic type represents the 400-600 year postdisturbance development from standreplacing disturbance to an all-aged stand. The second type, "oscillation dynamics", is associated with medium-severity disturbances, e.g. windthrows, in those stands which had been close to an all-aged structure. The cycle lasts 150-200 years. 


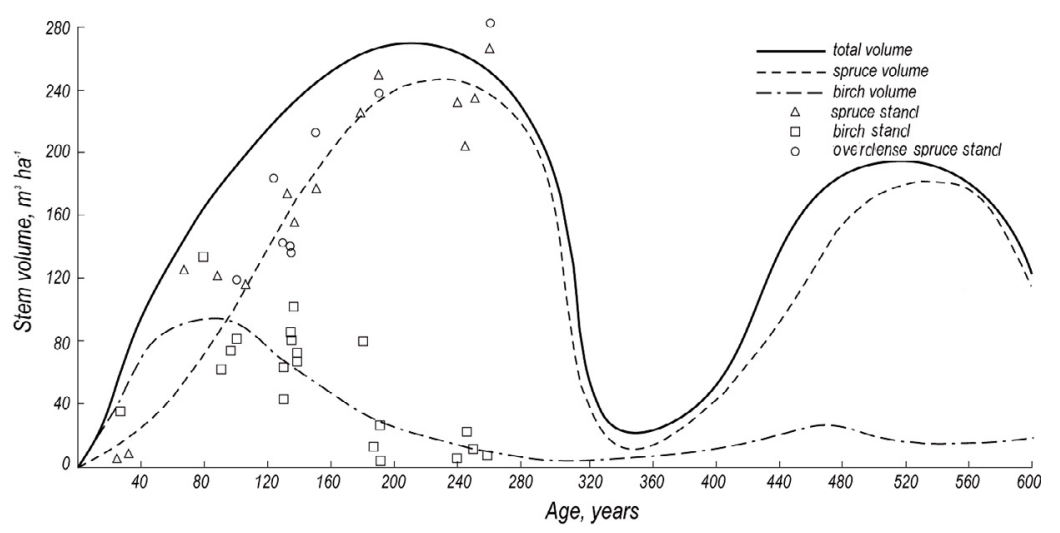

Figure 8. Development of stem volume $\left(\mathrm{m}^{3} \mathrm{ha}^{-1}\right)$ of spruce and birch after fire in the northern Hylocomium-Myrtillus forests in Finland according to Sirén (1955). The 600-years development consists of two wave-like phases, in Sirén's terminology the 'primary' and 'secondary' successions. The data points are available only for the former one. The figure was redrawn from Sirén's (1955) figures 24 and 27.

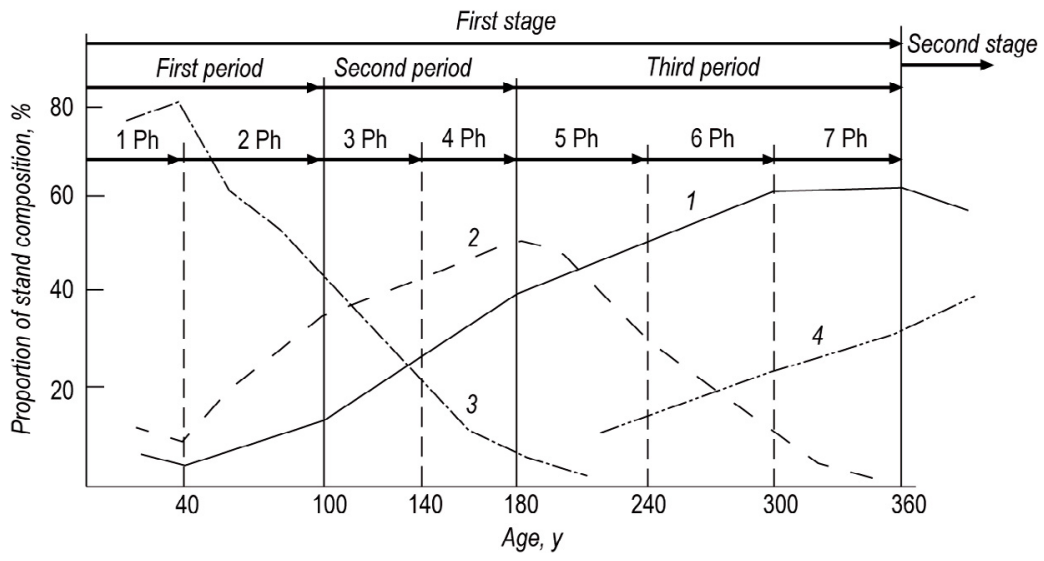

Figure 9. Successional development of green-moss-herb Siberian pine forest stand. 1: Siberian pine (Pinus sibirica), 2: Siberian spruce (Picea obovata) and fir (Abies sibirica), 3: deciduous species: birch (Betula pubescens, B. verrucosa, B. krylovi) and aspen (Populus tremula), 4: new cohorts for spruce, fir and Siberian pine, Ph: phase. The figure was redrawn from Smolonogov (1990).

The third dynamic type, "die-off - regeneration", is associated with "nonsignificant" destruction of all-aged stands lasting several decades. The fourth type, "uneven, wave-like regeneration process in pristine spruce forests", is associated with periodical disturbances. The cycle lasts from several decades to $100-150$ years depending on the severity of disturbances. Dyrenkov (1984) showed that this fourth type, which in modern understanding can be called cohort dynamics (Angelstam and Kuuluvainen, 2004) predominates in most boreal forests. Finally, the fifth type in Dyrenkov's system is an "even regeneration process of all-aged stands" (fine-scale gap dynamics). According to Dyrenkov (1984), the changes in tree species composition between Picea $\leftrightarrow$ Betula, Populus and Tilia can occur only in the first and second dynamic types, the changes in Picea $\leftrightarrow$ Pinus can occur only in the second type, while Picea $\leftrightarrow$ Abies, Pinus sibirica can occur in the second, third and fourth types during successions in polydominant coniferous stands.

The above examples illustrate that several classification schemes were developed to describe the dynamics of dark coniferous taiga, i.e. forests dominated by Norway spruce, or Siberian spruce, fir or pine. In general, two main dynamic types were described: (1) endogenous stand development leading to formation of the uneven-aged or all-aged stand structure associated with small-scale dynamics, stabilization of volume and increment and, in some studies, concurrent with a gradual change in site conditions, and (2) dynamics associated mainly with more severe and larger-scale disturbances. This distinction provided a framework for later studies.

\subsubsection{Light coniferous taiga}

The dynamics of the light coniferous forests, i.e. shadeintolerants such as Scots pine and larch, are usually associated with concurrent low-intensive fires. However, nonpyrogenic endogenous successions of Scots pine forests have been described as well (Zyabchenko, 1970).

Zyabchenko (1984) suggested a scheme for endogenous development of Scots pine forest based on empirical data 


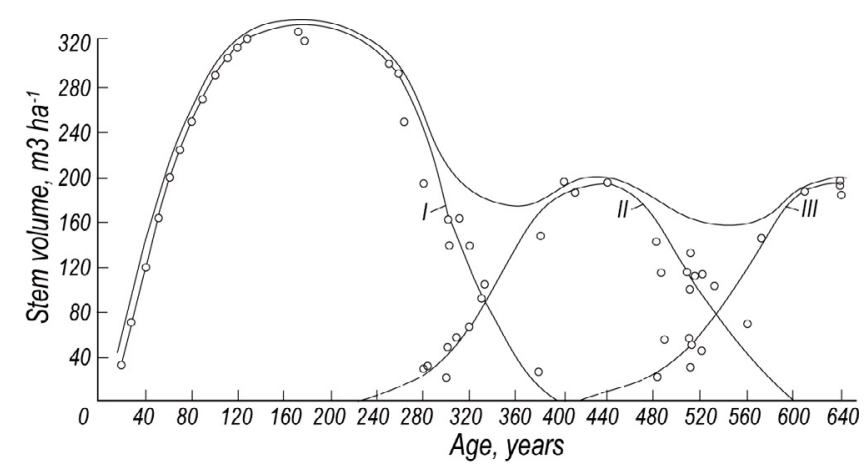

Figure 10. Dynamics of the standing volume of Scots pine (Pinus sylvestris) (Pinetum vacciniosum, dry and poor forest type) stand in Karelia and Murmansk region based on 53 sample plots. I, II, III cohorts. The figure was redrawn from Zyabchenko (1984).

acquired from the Kola Peninsula, Murmansk region and Karelia (Fig. 10). The succession begins from open areas (burned areas, clearcuts) colonized by pine and is completed by mortality of the first tree generation and appearance of a new one from advanced regeneration. Usually this occurs at approximately 280 years of stand age, and by 400 years of stand age almost all the trees of the first generation have died. A feature of the first phase is the absence of a period of suppression by dominant trees. The stands are even-aged and characterized by high standing volume, high density and no pronounced vertical stratification. The time of entry of the second generation into the upper tree layer (at 280-300 years) corresponds to the second phase of development. This phase lasts until die-off of the second generation at 480-500 years. At this stage, the stands are uneven-aged, with at least two generations of trees, pronounced vertical structure and less standing volume, compared with the stands of the first phase. Most pines of the second generation remain suppressed for circa 80 years. After die-off of the second pine generation, the favourable conditions for regeneration of the third generation are developed. In approximately 600 years after colonization of open land, the uneven-aged stands are formed, with two or more age cohorts, or generations of trees, and with almost all trees having experienced a suppression period. At this time the third and final phase in endogenous development of a pine stand begins, resulting in a stand reaching the "climax" stage, according to Zyabchenko (1984).

The process of endogenous forest development can be interrupted and reset back to the starting point by severe standreplacing fires, whereas less intense surface fires create a cyclic regeneration pattern of fire-adapted tree species such as Scots pine and Siberian larch. The regeneration of the latter type of forests has a wavy-like character: the regeneration coincides with favourable conditions (seedbeds and canopy gaps) created by fires. Utkin (1965) went so far as to claim that there are no larch-dominated forests in central Yakutiya that have developed without fire. The cohort dynamics of larch forests due to periodic surface fires and cyclic dynamics of their age structure were verified by Glagolev $(1975 ; 1976)$ and Shevelev (1999).

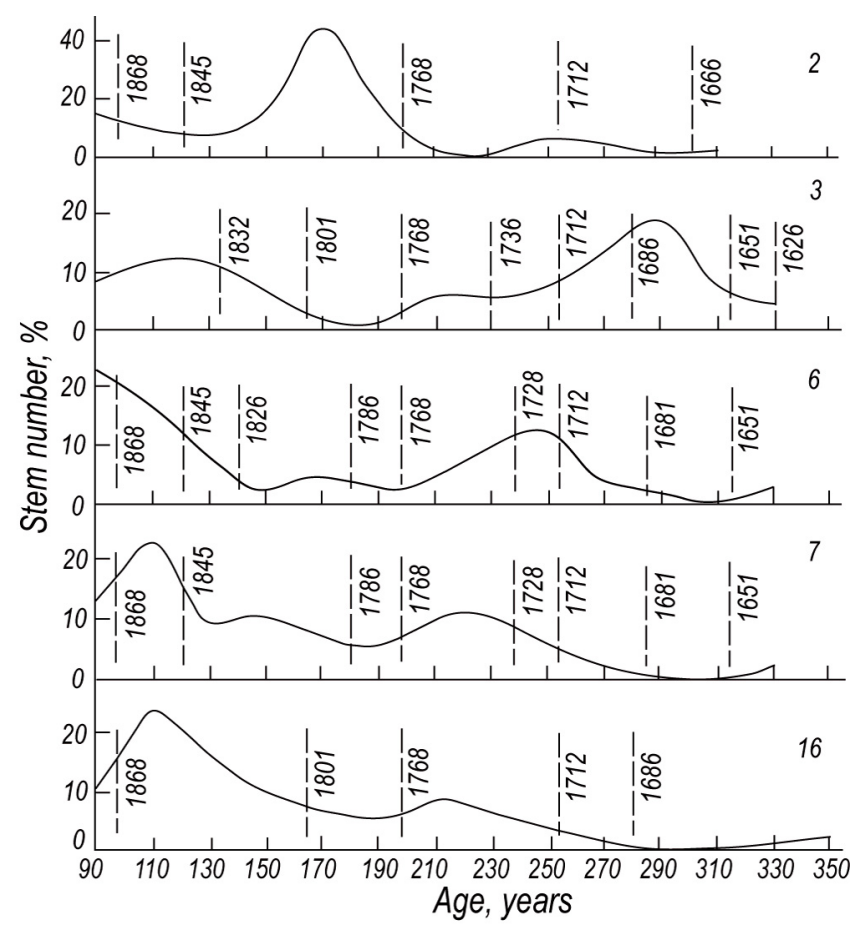

Figure 11. Age distribution of trees in uneven-aged Scots pine (Pinus sylvestris) forest stands in Russian Karelia with dated surface fires (shown with vertical dashed lines). 2, 3, 6, 7, 16 are numbers of the sample plots. The figure is redrawn from Zyabchenko (1986).

Fire severity determines the subsequent successional dynamics: even-aged stands are formed after high-severity fires, while uneven-aged stands are formed by low-severity surface fire regimes. Zyabchenko (1984) provided evidence for the higher proportion of uneven-aged stands under poorer site conditions than on more fertile sites; he also described a wave-like cohort dynamics induced by fire for pine forests in Karelia (Figs. 10 and 11).

Verkhunov (1979) described the development of Scots pine stands in Siberia. He distinguished the following developmental stages for each generation: (1) undergrowth initiation and stem exclusion, by 60 years; (2) mature forest, by 120 years; (3) transition from maturity to over-mature by 180 years; (4) old growth by 320 years and (5) very old growth and dieoff. Verkhunov (1979) showed that each generation repeats this developmental scheme and associated the regeneration of each new pine cohort or generation with the occurrence of surface fire.

The successional stage of the stand affects the survival of trees in a fire and their subsequent successional development. Verkhunov (1970) described the fire - forest community interactions in Scots pine stands in Siberia, showing that trees younger than 30-40 years old die in the fire, and that the successional dynamics of these stands are interrupted. In older but pre-mature even-aged pine stands, high but spatially heterogeneous fire-induced mortality leads to appearance of gaps filled by regeneration of the next cohort. In mature even-aged stands, surface fires cause mortality of only suppressed small trees. 
However, the poor light conditions do not allow the next cohort to establish. Finally, in overmature even-aged stands, fire kills not only small but also older weak trees. Thus, part of the old tree cohort dies off, opening space and stimulating recruitment of a new tree cohort. Subsequently, an uneven-aged stand is gradually formed. Surface fires occurring in uneven-aged stands create complex tree age structures. However, mortality of older trees and the subsequent recruitment of new ones are not abrupt events but gradual processes that broaden tree age distributions (Verkhunov, 1970).

In western Siberia, the types of Scots pine forest were ranked by Verkhunov (1970) in decreasing order of fire frequency and severity as follows: lichen, cowberry, green-mossherb, long-moss and sphagnum sites. The highest degree of fire-induced uneven-agedness was observed in the lichen and cowberry types (Verkhunov, 1970). The reviewed studies indicate that in the light coniferous taiga surface fire is the central factor driving cohort dynamics and supporting complex uneven-aged stand structures in Scots pine and Siberian larchdominated forests.

\section{A SYNTHESIS OF STAND DYNAMICS}

The studies reviewed demonstrate that the interrelationships between the forest-forming factors, mainly dominant tree species and site conditions together with associated disturbance regimes, lead to a wide range of natural variability in stand structures. Accordingly, multiple successional pathways in stand development have been demonstrated both in dark and light taiga forests. In general, all-aged stands are gradually formed over several hundreds of years of endogenous succession. This endogenous development can be interrupted by stand-replacing or partial disturbances, such as fires, windthrows and insect outbreaks.

Boreal forest dynamics can be classified according to time since disturbance, prevailing disturbance regime, site type and stand characteristics, into the following stand dynamic types:

1. Even-aged, compositional change development,

2. Even-aged, mono-dominant development,

3. Cohort dynamics,

4. Fine-scale gap dynamics.

These stand dynamic types are related to certain site conditions, age and diameter distribution, dominant species, severity of disturbance, time since last disturbance, and spatial structure (Tab. I). Even-aged dynamics (types 1 and 2, Tab. I) are pronounced after stand-replacing disturbances such as fires, windthrows and insect outbreaks. The more nutrient-rich the site conditions, the higher is the probability of type 1 , with a more pronounced dominant role of deciduous tree species (birch, aspen) in early succession after disturbance, and the longer is the delay in achieving the dominance of coniferous tree species (spruce, fir). In stand dynamic type 1, the replacement of tree species lasts from 60 up to 180-200 years. The mechanism of development may vary depending on the size and decline age of short-living hardwoods in the stand composition. This dynamic type represents a mechanism of replace- ment of light taiga by dark taiga in the absence of fire and back e.g. in case of recurrent surface fires.

Mono-dominant development (type 2) occurs on poor sites where a single tree species is a superior competitor, such as Scots pine on dry heaths (Aaltonen, 1919) and spruce in poorly drained spruce forests (Fedorchuk et al., 1998).

In both stand dynamic types 1 and 2, successional development may be interrupted by disturbance. However, in the absence of disturbance and with senescence of the trees from the initial cohort, canopy gaps are gradually formed, leading to a patchy recruitment of new cohorts and the stand shifts first to type 3 dynamics and then gradually, if free from major disturbances, over lengthly periods, toward type 4 dynamics characterized by all-aged forests. In dynamic type 2 , this process requires significantly more time than type 1 .

Cohort dynamics (type 3) prevail when recurring partial disturbances stimulate cyclic regeneration processes and lead to a multimodal stand age structure (Tab. I). In cohort dynamics different phases can be distinguished: a regeneration phase, a phase of growing stock increment (young cohorts predominate), stabilization and growing stock decline (old cohorts predominate) (Fedorchuk et al., 1998). The oscillation of these phases is dependent on the disturbance type and severity that influence regeneration conditions: from decades in the case of mid-severity windthrow to centuries in the case of stand decline due to insect attack, e.g., by the Siberian silk moth.

Fedorchuk et al. (1998) showed that when a stand has escaped exogenous disturbances for lengthy periods, the pronounced oscillations in tree mortality and regeneration are dampened, and the stand dynamics become characterized by a fine-scale mosaic of stochastic mortality and regeneration processes. This is type 4 dynamics, in which the stand can be considered to be in "quasi-equilibrium" and all tree age classes are continuously present. These late-successional stands are not necessarily monodominant. Usually the percentage of deciduous trees increases with increase in site productivity (Pugachevsky, 1992).

The endogenous process of transition from the first or second to fourth types of dynamics can last for centuries. Based on studies of the chronosequence of forest ecosystems, Kazimirov (1971) (Fig. 6) in Russian Karelia, middle Boreal Zone and Pugachevsky (1992) in the Tver region (the Central Biosphere Forest Reserve, southern Boreal Zone) concluded that formation of all-aged Norway spruce stands after a standreplacing disturbance could require $600-700$ years, depending on site conditions.

\section{MANAGEMENT IMPLICATIONS}

We conclude that if the aim is to manage the forest to maintain its ecological characteristics it is necessary to take into account the high diversity of stand structures and developmental pathways naturally occurring in Eurasian boreal forests. Interestingly enough, leading Russian forest scientists in the early 20th century already warned against searching for a single universal silvicultural method (Bogushevsky, 1912; Morozov, 1925; Tkachenko, 1931; Yashnov, 1934). They emphasized that the forest represents a geographic phenomenon 


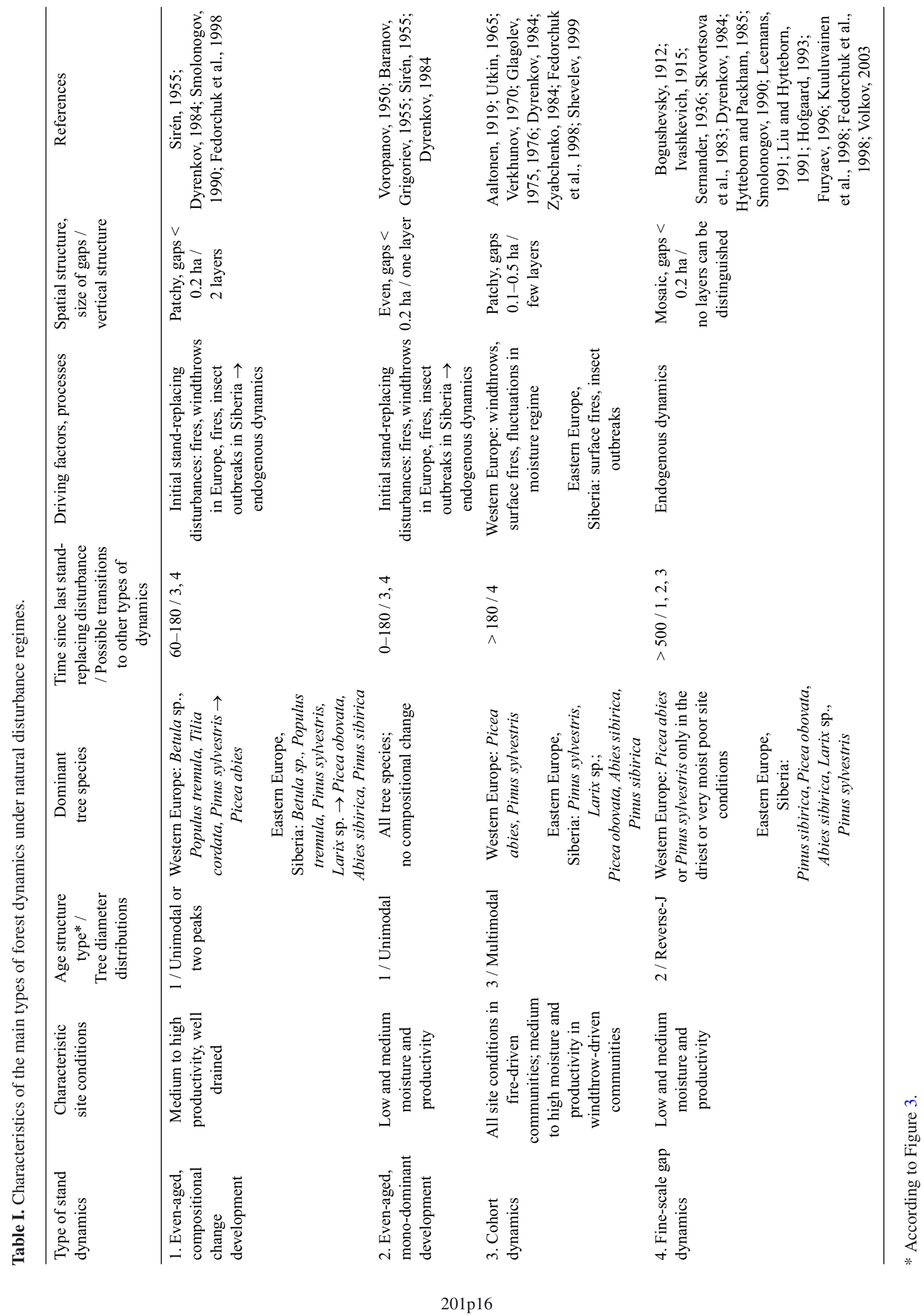


and that the choice of management method should be based on economic and ecological conditions as well as on the natural characteristics of forest stands. Similarly, in Finland Kalela (1948) emphasized that natural stand structures and developmental processes should form the basis for silviculture. Recently, reintroducing the selective system and other unevenaged silvicultural systems back to forestry has been suggested and widely discussed in Scandinavian countries and Russia as important tools for sustainable forestry (e.g. Angelstam, 1998; Kuuluvainen, 2002; Lähde et al., 1999; Volkov, 2003).

Ecological forestry can be developed, based on the existing knowledge of natural stand structures and dynamics, such as the classification of stand dynamics presented in Table I (see also Angelstam, 1998; Angelstam and Kuuluvainen, 2004; Bergeron et al., 2002). For landscape-level forest management, it is important first to estimate the natural proportions of different stand dynamics types. Then, for each type, taking into account tree species composition and site conditions, silvicultural methods that match the natural dynamics can be applied (Dyrenkov and Shergol'd, 1973; Kangur et al., 2005; Pobedinsky, 1980; Tikhonov and Zyabchenko, 1990).

Acknowledgements: The manuscript was prepared under the framework of the SNS Network "Natural Disturbance Dynamics Analysis for Forest Ecosystem Management". We thank Jürgen Kusmin for redrawing the figures from old papers, Piret Trei and Anton Kuznetsov for help with preparing the literature and Victor Fedorchuk and Ilkka Vanha-Majamaa for fruitful discussions and comments on the manuscript. James Thompson corrected English.

\section{REFERENCES}

Aaltonen V.T., 1919. On the natural regeneration of heath forests in Finnish Lapland I (Kangasmetsien luonnollisesta uudistumisesta Suomen Lapissa I). Commun. Inst. Forest. Finlandiae 1: 1-319 (in Finnish with German summary).

Abaturov Yu.D., Pis'merov A.V., and Orlov A.Y., 1988. Pristine dark coniferous forests of southern taiga ("Kologrivskij les" reserve) (Korennye temnokhvojnye lesa yuzhnoj taigi (rezervat "Kologrivskij les"), M., Nauka, 220 p. (in Russian).

Ahti T., Hämet-Ahti L., and Jalas J., 1968. Vegetation zones and their sections in northwestern Europe. Ann. Bot. Fenn. 5: 169-211.

Alekseev S.V., 1948. Cuttings in the forests in the North (Rubki v lesakh Severa), M., L., 64 p. (in Russian).

Angelstam P.K., 1998. Maintaining and restoring biodiversity in European boreal forests by developing natural disturbance regimes. J. Veg. Sci. 9: 593-602.

Angelstam P. and Kuuluvainen T., 2004. Boreal forest disturbance regimes, successional dynamics and landscape structures - a European perspective. Ecol. Bull. 51: 117-136.

Anonymous, 1967. The uneven-aged forests and forestry in Siberia, Far East and Urals (Raznovozrastnye lesa Sibiri, Dal'nego Vostoka i Urala i vedeniye khozyajstva $\mathrm{v}$ nikh), Zhukov A.V. (Ed.), Krasnoyarsk, Forest Institute, RAS (in Russian).

Anonymous, 1991. The theory of forest-forming process (Teoria lesoobrazovatel'nogo protsessa). Abstracts Int. Conf. Krasnoyarsk, 186 p. (in Russian).

Arnborg T., 1943. Granberger. A plantbiological study of a pristine spruce forest in southern Lapland with special reference to forest types and regeneration (Granberget. En vextbiologisk undersökning av ett sydlapplänskt granskogområde med särskild hänsyn till skogtyper och föryngring), 290 p. (in Swedish).

Attiwill P.M., 1994. The disturbance dynamics of forest ecosystems: the ecological basis for conservative management. For. Ecol. Manage. 63: $247-300$.
Baranov N.I. and Grigoriev K.I., 1955. The spruce forests in the North (El'niki Severa), M., L., 47 p. (in Russian).

Bergeron Y., Leduc A., Harvey B., and Gauthier S., 2002. Natural fire regime: a guide for sustainable management of the Canadian boreal forest. Silva Fenn. 36: 81-95.

Bhiry N., Payette S., and Robert E.C., 2007. Peatland development at the arctic tree line (Quebec, Canada) influenced by flooding and permafrost. Quat. Res. 67: 426-437.

Bitrikh A.A., 1908. Study of the forests of the Ust'-Sysolsky uyezd (Ocherk lesov Ust'-Sysolskogo uezda). Lesnoy Journal 4-5: 441-464 (in Russian).

Bogoslovsky S.A., 1921. Study of the increment of an uneven-aged spruce forest in connection with demands of selective harvesting system (Issledovaniye prirosta raznovozrastnogo elovogo lesa v svyazi s voprosami vyborochnogo khozyaystva). Bulletin Nauchnogo i Tehknologicheskogo Obschestva: 3-57 (in Russian).

Bogushevsky V., 1912. Apropos of article by Rozhkov, Forest inventory in the northern forests" (Po povodu statyi Rozhkova "K ustroystvu severnykh lesov"). Lesnoy Journal 2-3: 299-310 (in Russian).

Buryak L.V., Luzganov A.G., Matveev P.M., and Kalenskaya O.P., 2003. Impact of surface fires on formation of light-coniferous forests in the South of Middle Siberia (Vliyaniye nizovykh pozharov na formirovaniye svetlokhvojnykh nasazhdenij juga Sredney Sibiri), Krasnoyarsk, 206 p. (in Russian).

Buzykin A.I., 1967. Age structure of pine forests of Eastern Pribajkalye (O vozrastnom stroenii sosnovykh drevostoev Vostochnogo Pribajkalya). In: The uneven-aged forests and forestry in Siberia, Far East and Urals (Raznovozrastnye lesa Sibiri, Dal'nego Vostoka i Urala i vedeniye khozyajstva v nikh), Krasnoyarsk. pp. 14-18 (in Russian).

Cajander A.K., 1909. On forest types. Über Waldtypen. Acta For. Fenn. 1(1): $1-175$.

Cajander A.K., 1926. The theory of forest types. Acta For. Fenn. 29(3): $1-108$.

Clements F.E., 1904. The development and structure of vegetation. Botanical Survey of Nebraska 7, Studies in the vegetation of the state, Lincoln, Nebraska.

Clements F.E., 1916. Plant succession. Carnegie Institute of Washington, Publication 242, Washington, DC.

Dekatov N.E., 1961. Measures for natural regeneration during mechanical harvesting (Meropriyatiya po vozobnovleniyu lesa pri mekhanizirovannykh lesozagotovkakh), M., L., 276 p. (in Russian).

Dyrenkov S.A., 1984. Structure and dynamics of taiga spruce forests (Struktura i dinamika tayezhnykh el'nikov), Leningrad, Nauka Publ., 176 p. (in Russian).

Dyrenkov S.A., Shergol'd O.E., 1973. Cuttings of the main usage in middle- and southern boreal spruce forests in European part of the USSR (Rubki glavnogo pol'zovaniya v el'nikakh sredne- i yuzhnotaezhnoj podzon evropejskoj chasti SSSR), Leningrad, 36 p. (in Russian).

Ermolenko P.M., 1967. Age structure of pine forest stands in country between rivers Ija and Oka in Eastern Sayan (Vozrastnoye stroenije sosnovikh drevostoev Iya-Okinskogo mezhdurechya Vostochnogo Sayana). In: The uneven-aged forests and forestry in Siberia, Far East and Urals (Raznovozrastnye lesa Sibiri, Dalnego Vostoka i Urala i vedeniye khozyajstva v nikh), Krasnoyarsk, pp. 47-52 (in Russian).

Falaleev R.N., 1985. Forests of Siberia (Lesa Sibiri), Krasnoyarsk, 134 p. (in Russian).

FAO, 2007. Fire management - global assessment 2006, FAO Forestry paper 151, Rome, Italy.

Fedorchuk V.N., Kuznetsova M.L., Andreeva A.A., and Moiseev D., 1998. Forest reserve of "Vepssky les". Forestry research (Rezervat "Vepsskij Les" Lesovodstvennyje issledovanija), St-Pet. For. Res. Inst. Publ., 208 p. (in Russian).

Frey T.E.A., 1978. The Finnish school and forest site-types. In: R.H. Whittaker (Ed.), Classification of plant communities, Dr. W. Junk Publishers, The Hague, pp. 81-110.

Furyaev V.V., 1970. Impact of fires and Siberian silkworm outbreaks on formation of forests between Ket' and Chulym rivers (Vliyaniye pozharov i massovykh razmnozhenij sibirskogo shelkopryada na formirovaniye lesov Ket'-Chulymskogo mezhdurechya), Forest Sciences (Voprosy lesovedenya) 1: 408-421 (in Russian). 
Furyaev V.V., 1996. The role of fires in forest-forming process (Rol' pozharov v protsesse lesoobrazovaniya), Novosibirsk, Nauka, $253 \mathrm{p}$. (in Russian).

Glagolev V.A., 1975. Some features of the structure and development of an uneven-aged larch stand in the Northern part of Primorye (Nekotorye cherty stroyeniya i razvitiya raznovozrastnogo listvennichnogo drevostoya severnogo Primorya). Russian Forest Sciences (Lesovedenye) 2: 98-103 (in Russian).

Glagolev V.A., 1976. Peculiarities of the age structure of larch forests in the Central Sikhote-Alin' in connection with fires (Osobennosti vozrastnogo stroeniya lictvennichnykh lesov srednego Sikhote-Alinya v svyazi s pozharami). Russian Forest Sciences (Lesovedenye) 5: 69-77 (in Russian).

Gorshkov V.V., Stavrova N.I., and Tarasova V.N., 2004. Damage of Pinus sylvestris trees and tree layer in pine forests due to fire in the European North (Povrezhdeniye derevyev sosny obyknovennoj i drevesnogo yarusa sosnovikh lesov Evropejskogo severa v rezul'tate pozharov). Russian Forest Science (Lesovedeniye) 5: 10-19 (in Russian).

Gorsky P.V., 1962. Methodological recommendations for development of growth tables of uneven-aged stands and techniques of their compilation (Metodicheskiye polozhenyia po sostavleniyu eskizov tablits khoda rosta raznovozrastnykh nasazhdenyi i tekhnika sostavlenya ikh), Alma-Ata, 32 p. (in Russian).

Gromtsev A., 2002. Natural disturbance dynamics in the boreal forests of European Russia: a review. Silva Fenn. 36: 41-55.

Granström A., 2001. Fire management for biodiversity in the European boreal forest. Scand. J. For. Res. Suppl. 3: 62-69.

Gromtsev A.N., 1996. Retrospective analysis of natural fire regimes in landscapes of Eastern Fennoscandia and problems of their anthropogenic transformation. In: Goldammer J.G. and Furyaev V.V. (Eds.), Fire in ecosystems of boreal Eurasia, Dortrecht-BostonLondon. pp. 45-54.

Gusev I.I., 1964. The structure and peculiarities of mensuration in spruce forests in the North (Stroenye i osobennosti taksatsii el'nikov Severa), Moskow, 232 p. (in Russian).

Hofgaard A., 1993. Fifty years of change in a Swedish boreal old-growth Picea abies forest. J. Veg. Sci. 4: 773-782.

Huse S., 1964. Structural forms of primeval forest stands in Övre Pasvik. Structurformer hos urskogbestand i Ovre Pasvik. Institutt for Skogkjotsel. Norger Landbrukshogskole, Vollebekk (In Norwegian with German summary).

Hytteborn H. and Packham J.R., 1985. Left to nature: forest structure and regeneration in Fiby urskog, central Sweden. Arbor. J. 9: 1-11.

Hytteborn H., Maslov A.A., Nazimova D.I., and Rysin L.P., 2005. Boreal forests of Eurasia. In: Andersson F. (Ed.), Coniferous forests, Ecosystems of the World, Vol. 6, Elsevier, Amsterdam, pp. 23-99.

Ilvessalo Y., 1920. Growth and yield tables for pine, spruce and birch forests in southern Finland (Kasvu- ja tuottotaulukot Suomen eteläpuoliskon mänty-, kuusi- ja koivumetsille). Acta For. Fenn. 15: 1-96 (in Finnish).

Ilvessalo Y., 1937. Growth and development of natural normal stands in Peräpohjola (Peräpohjolan luonnonnormaalien metsiköiden kasvu ja kehitys). Commun. Inst. For. Fenn. 24: 1-168 (in Finnish with English summary).

Ilvessalo Y., 1967. On the development of natural normal stands in Kainuu and its vicinity (Luonnonnormialen metsiköiden kehityksestä Kainuussa ja sen lähiympäristössä). Acta For. Fenn. 81: 1-85 (in Finnish).

Ilvessalo Y., 1970. Natural development and productivity of stands on mineral soil sites in northern Lapland (Metsiköiden luontainen kehitys- ja puuntuottokyky Pohjois-Lapin kivennäismailla). Acta For. Fenn. 108: 1-43 (in Finnish).

Ivanov V.A., 1996. Mechanism of fire emergence from lightning (Mehanizm vozniknoveniya lesnogo pozhara ot molnii). Siberian Ecological Journal (Sibirskij ekologicheskij zhurnal) 1: 103-107 (in Russian).

Ivashkevich B.A., 1915. Manchurian forest. Description for the Eastern forest concession of the community of Chinese-Eastern Railway with the plan of economy (Manchzhurskiy les. Opisaniye Vostochnoy lesnoy kontsessii obschestva Kitaisko-Vostochnoy zheleznoy dorogi i plan khozyaistva na neyo), Issue 1, Harbin (in Russian).
Ivashkevich B.A., 1929. The virgin forest, peculiarities of its structure and development (Devstvenniy les, osobennosti ego stroenya i razvitiya). Forestry and Forest Industry (Lesnoye khozyastvo i Lesnaya Promyshlennost') 10-12: 36-44 (in Russian).

Jakovlev G.V., 1983. Age structure of forest stands in Southern taiga European part of USSR (Vozrastnaya struktura drevostoev juzhnoj tajgi evropejskoj chasti SSSR). Russian Forest Sciences (Lesovedenye) 5: 33-40 (in Russian).

Kalela E.K., 1948. Nature-based treatment of forests (Luonnonmukainen metsien käsittely) Silva Fenn. 64: 16-32 (in Finnish).

Kangur A., Korjus H., Jõgiste K., and Kiviste A., 2005. A conceptual model of forest stand development based on permanent sample-plot data in Estonia. Scand. J. For. Res. 20 (Suppl 6): 94-101.

Kataeva K.V. and Korzukhin M.D., 1987. Dynamics of the darkconiferous-Siberian pine forests (Dinamika temnokhvoynokedrovikh lesov), M., 115 p. (in Russian).

Kaurichev I.S., Panov N.P., Rozov N.N., Stratonovich M.V., and Fokin A.D., 1989. Soil science (Pochvovedenije), 4th Ed., Agropromizdat, Moscow (in Russian).

Kazimirov N.I., 1971. Spruce forests of Karelia (El'niki Karelii), Leningrad, Nauka, 140 p. (in Russian).

Kolesnikov B.P., 1956. The Siberian pine forests of the Far East (Kedrovye lesa Dal'nego Vostoka), M., L. Russian Academy of Sciences Publ, 262 p. (in Russian).

Komin G.E., 1983. Successions in uneven-aged forests and possibilities of their prediction (Smeny pokolenij v raznovozrastnykh lesakh i vozmozhnosti ikh prognoza). Forest Sciences (Lesovedenye) 4: 4955 (in Russian).

Komin G.E., 1993. Cyclicity of the forest-forming process (Tsyclichnost' lesoobrazovatel'nogo processa). Russian Forest Sciences (Lesovedenye) 1: 3-9 (in Russian).

Komin G.E., 2003. Some aspects of dynamics of stand age structure (Nekotorye aspekty dinamiki vozrastnoj struktury drevostoev). Forest Sciences (Lesovedenye) 4: 54-6 (in Russian).

Konstantinov V.D. and Gorozhankina S.M., 1995. Regeneration dynamics of middle boreal forest ecosystems: Central Siberian Biosphere Reserve case study (Vosstanovitel'naya dinamika lesnykh ekosistem srednej tajgi na primere Tsentral'no-Sibirskogo biosfernogo zapovednika). Lesovedenye (Russian Forest Science) 2: 13-21 (in Russian).

Korchagin A.A., 1956. The spruce forests in the west Pritimanye in the basin of river Mezenskaya Pizhma (their structure and regeneration) (Eloviye lesa Zapadnogo Pritimanya v basseyne reki Mezenskoy Pizhmi (ikh stroenye i vozobnovlenye). Proceedings of the Leningrad State University, Geographical Series 11: 111-239 (in Russian).

Kostuchenko I.S., 1977. Dynamics of dark-coniferous-Siberian pine forests in Western Siberia (Dinamika temnokhvoyno-kedrovykh lesov Zapadnoy Sibiri), Doctoral thesis, Krasnoyarsk, 242 p. (in Russian).

Kozachenko I.I., 1912. Arguing for selection felling (V zaschitu vyborochnikh rubok), StP., 19 p. (in Russian).

Kozin E.K., 1982. On cyclic development of virgin forests in the SikhoteAlin' (O tsyklichnosti razvitiya devstvennykh lesov Sikhote-Alinya). Forest Sciences (Lesovedenye) 3: 24-31 (in Russian).

Kravchinsky D.M., 1901. Consequences of clear cuts in the forests in northern and middle Russia (O posledstviyakh sploshnyhk rubok v lesakh severnoj i srednej Rossii), StP, PP “Sojkin”, 31 p. (in Russian).

Kurbatskij N.P., 1954. Methodical guidance for developing local classifications of forest fire hazard (Metodicheskiye ukazaniya dlya razrabotki mestnykh shkal pozharnoj opasnosti v lesakh), Leningrad, Lenoblizdat (in Russian).

Kurbatskij N.P., 1964. Forest fire problem (Problema lesnykh pozharov). In: Emergence of forest fires (Vozniknoveniye lesnykh pozharov), pp. 5-60 (in Russian).

Kurzin N.I., 1958. Growth tables of mixed deciduous-spruce and spruce-deciduous forest stands of the watershed between Volga and Dvina (Tablitsi khoda rosta smeshannikh listvenno-elovikh i elovolistvennikh nasazhdeniy vodorazdela Volgi i Severnoy Dviny), L., 18 p. (in Russian).

Kuuluvainen T., 1994. Gap disturbance, ground microtopography, and the regeneration dynamics of boreal coniferous forests in Finland: a review. Ann. Zool. Fenn. 31: 35-51. 
Kuuluvainen T., 2002. Natural variability of forests as a reference for restoring and managing biological diversity in boreal Fennoscandia. Silva Fenn. 36: 97-125.

Kuuluvainen T., Syrjänen K., and Kalliola R., 1998. Structure of a pristine Picea abies forest in northeastern Europe. J. Veg. Sci. 9: 563-574.

Lähde E., Laiho O., Norokorpi Y., and Saksa T., 1991. The structure of advanced virgin forests in Finland. Scand. J. For. Res. 6: 527-537.

Lähde E., Laiho O., and Norokorpi Y., 1999. Diversity-oriented silviculture in the boreal zone of Europe. For. Ecol. Manage. 118: 223-243.

Leemans R., 1991. Canopy gaps and establishment patterns of spruce (Picea abies (L.) Karst.) in two old-growth coniferous forests in central Sweden. Vegetatio 93: 157-165.

Leibundgut H., 1982. Virgin European forests on mountain ranges (Europäische Urwälder der Bergstufe), Bern, Stuttgart, 308 S (in German).

Levin V.I. and Gusev I.I., 1958. The growth trend of even-aged spruce forests in 3th, 4th and 5th site classes in Arkhangelsk region (Khod rosta odnovozrastnykh el'nikov III, IV, V klassov boniteta Arkhangelskoy oblasti). Forest Journal (Lesnoy Journal) 6: 24-30 (in Russian).

Liu Q.H. and Hytteborn H., 1991. Gap structure, disturbance and regeneration in a primeval Picea abies forest. J. Veg. Sci. 2: 391-402.

Maksimov V.A., 1967. The structure and growth of Lapland pine in the Murmansk region (Stroenye i khod rosta nasazhdeniy sosny Laplandskoy v Murmanskoy oblasti). In: Studies on boreal forestry in the European North (Voprosy taezhnogo lesovodstva na Evropeyskom Severe), M., pp. 79-87 (in Russian).

Mal'gin N.G., 1842. Some comments on growing of Siberian pine (Nekotorye zamechaniya o proizrastanii sibirskogo kedra). Lesnoy Journal 2: 332-361 (in Russian).

Man'ko Y.I., 1967. The fir-spruce forests in the northern SikhoteAlin' (Pikhtovo-Elovyie lesa Severnogo Sikhote-Alinya), L., Nauka, 244 p. (in Russian).

Man'ko Y.I., 1996. Geographical peculiarities of the forest-forming process in dark coniferous forests in the Far East (Geograficheskiye osobennosti lesoobrazovatel'nogo protsessa v temnokhvoinykh lesakh Dal'nego Vostoka). Russian Forest Science (Lesovedenye) 4: 3-11 (in Russian).

Man'ko Y.I., 2004. The forest-forming process and classification of forest vegetation (Lesoobrazovatel'niy protsess i ksassifikatsia lesnoy rastitelnosti). Russian Forest Sciences (Lesovedenye) 5: 3-9 (in Russian).

Masing V. (Ed.), 1979. Botany: vegetation ecology, geography, geobotany, Valgus, Talinn (in Estonian).

Melekhov I.S., 1947. Nature of a forest and forest fires (Priroda lesa i lesnye pozhary), Arkhangelsk, OGIS, 60 p. (in Russian).

Melekhov I.S., 1948. Impact of fires on forest (Vliyaniye pozharov na les), M., Goslestekhizdat, 127 p. (in Russian).

Melekhov I.S., 1962. Cuttings of the main usage (Rubki glavnogo pol'zovanya), M., 329 p. (in Russian).

Melekhov I.S., 1980. Forest science (Lesovedeniye), M., 403 p. (in Russian).

Moiseenko S.N., 1967. Age structure of Korean pine stands (K voprosu o vozrastnoj structure i stroenii drevostoev kedra korejskogo). In: The uneven-aged forests and forestry in Siberia, Far East and Urals (Raznovozrastnye lesa Sibiri, Dalnego Vostoka i Urala i vedeniye khozyajstva v nikh), Krasnoyarsk, pp. 111-121 (in Russian).

Morozov G.F., 1912. The doctrine about forest (Ucheniye o lese), Saint Petersburg, 83 p. (in Russian).

Morozov G.F., 1925. The doctrine about forest (Ucheniye o lese), Goslesizdat, 368 p. (in Russian).

Niklasson M. and Granström A., 2000. Numbers and sizes of fires: Longterm spatially explicit fire history in a Swedish boreal landscape. Ecology 81: 1484-1499.

Nikolov N. and Helmisaari H., 1992. Silvics of the circumpolar boreal tree species. In: A systems analysis of the global boreal forest, $\mathrm{H}$. Shugart R. Leemans, and G.B. Bonan (Eds.), pp. 13-84.

Nordlind E. and Östlund L., 2003. Retrospective comparative analysis as a tool for ecological restoration: a case study in a Swedish boreal forest. Forestry 76, 243-251.

Ogorodov N.V., 1951. The growth trend of closed spruce fir forests by forest types in the north-east of the European part of the USSR (Khod rosta somknutykh elovo-pikhtovikh nasazhdeniy po tipam lesa na severo-vostoke evropeyskoy chasti SSSR). Lesnoye Khozyaystvo 2: 49-55 (in Russian).

Oksanen J., 1990. Vegetation science in Finland. J. Veg. Sci 1: 277-282.

Orlov M.M., 1927, 1928. Forest inventory (Lesoustroystvo), M. L., Lesnoye khozyajstvo, lesnaya promyshlennost' i toplivo, V. 1, 2, 3 (in Russian).

Pakhuchij V.V., 1999 Virgin forests of Northern Ural region (Devstvennyje lesa Severnogo Priural'ya), Saint Petersburg, Nauka, 135 p. (in Russian).

Pobedinsky A.V., 1961. Cuttings of the main usage (Rubki glavnogo pol'zovanya), M., L., 147 p. (in Russian).

Pobedinsky A.V., 1980. Cuttings of the main usage (Rubki glavnogo pol'zovanija), Moskow, 191 p. (in Russian).

Pole F.R., 1906. About the forests of the northern Russia (O lesakh severnoy Rossii). Proceedings on experimental forest studies (Trudy po lesnomu opytnomu delu) 4: 76-131 (in Russian).

Pole F.R., 1915. A list of forestry and botanic-geographical literature in Northern Russia and Finland (Ukazatel' lesovodstvennoj i botanikogeograficheskoj literatury Severnoj Rossii i Finlyandii), Petrograd (in Russian).

Polyakov V.I. and Semechkin I.V., 2004. Dynamics and stability of uneven-aged Siberian pine stands in the Western Sayan Mountains (Dinamika i ustojchivost' raznovozrastnykh chernevykh kedrovnikov Zapadnogo Sayana). Russian Forest Sciences (Lesovedenye) 2: 1219 (in Russian).

Povarnitsin V.A., 1941. The forest types for Siberian larch in USSR (Tipy lesov sibirskoy listvennitsi SSSR). Proc. Siberian For. Tec. Inst. Goslesbumizdat (in Russian).

Povaritsin V.A., 1944. The Siberian pine forests in the USSR (Kedrovye lesa SSSR), Krasnoyarsk (in Russian).

Prozorov S.S., 1929. Burns in pine forests as centres of pest damages (Gari v sosnovykh lesakh kak ochagi zarazhenija, Omsk (in Russian).

Pugachevsky A.V., 1992. Populations of spruce: Structure, dynamics, controlling factors (Tsenopopulyatsii eli: struktura, dinamika, factory regulyatsii), Minsk, Navuka i tekhnika, 202 p. (in Russian).

Saari E., 1923. Forest fires in Finland. Acta. For. Fenn. 26: 1-155 (in Finnish with English summary).

Scherbakov I.P. and Chugunova R.V., 1960. Classification of burnt areas in the Southern-Western and Central Jakutija (O klassifikatsii garej v Yugo-Zapadnoj i Tsentral'noj Yakutii). Proceedings of Siberian Branch of RAS, No. 1 (in Russian).

Sedykh V.N., 1979. Forming the Siberian pine forests in Priob'e (Formirovaniye kedrovikh lesov Priobya), Novosibirsk, Nauka (in Russian).

Sedykh V.N., 1991. The forest-forming process: concepts and methods of study (Lesoobrazovatel'niy protsess: ponyatiya i metody issledovaniya). In: The theory of forest-forming process (Teoria lesoobrazovatel'nogo protsessa), Abstracts Int. Conf. Krasnoyarsk, pp. 139142 (in Russian).

Sernander R., 1936. Granskär och Fiby urskog (Summary: The primitive forests of Granskär and Fiby: a study of the part played by storm-gaps and dwarf trees in the regeneration of the Swedish spruce forest), Acta Phytogeogr. Suec. 8 (in Swedish).

Shanin S.S., 1967. Peculiarities of mensuration of uneven-aged pine and larch forest stands in Siberia (K voprosu ob osobennostyakh taksatsii raznovozrastnyhk sosnovykh i listvennichnykh drevostoev Sibiri). In: The uneven-aged forests and forestry in Siberia, Far East and Urals (Raznovozrastnye lesa Sibiri, Dalnego Vostoka i Urala i vedeniye khozyajstva v nikh), Krasnoyarsk, pp. 27-35 (in Russian).

Shavnin A.G., 1959. The experience of partition of uneven-aged sprucefir forests into separate age generations on the base of mensuration (Opyt raschlenenya raznovozrastnykh elovo-pikhtovikh nasazhdeniy na otdel'niye vozrastnye pokolenya po dannym perechislitel'noy taksatsii). Proc. Ural For. Tec. Inst., 3: 38-41 (in Russian).

Shevelev S.L., 1999. Age structure of larch forests in Middle Siberia (Vozrastnaya struktura listvennichnikov Srednej Sibiri). In: Forest mensuration and inventory, Krasnoyarsk, pp. 44-50 (in Russian).

Siitonen J., 2001. Forest management, coarse woody debris and saproxylic organisms: Fennoscandian boreal forests as an example. Ecol. Bull. 49: 11-41. 
Sinelschikov R.G., 1958. The age structure of spruce forests (K voprosu o vozrastnoj structure el'nikov). Forest Journal (Lesnoy Journal) 5: 13-22 (in Russian).

Sirén G., 1955. The development of spruce forest on raw humus sites in Northern Finland and its ecology. Acta For. Fenn. 62: 1-408.

Skvortsova E.B., Ulanova N.G., and Basevich V.F., 1983. Ecological role of windthrows (Ekologitcheskaya rol' vetrovalov). M., For. Ind. Publ., 192 p. (in Russian).

Smolonogov E.P., 1960. Dynamics of age structure of broad-leavedspruce-fir forests in the Urals ( $\mathrm{K}$ voprosu dinamiki vozrastnoy struktury i stroenya drevostoev shirokolistvenno-elovo-pikhtovikh lesov Urala). In: Proceedings of the Institute of Biology of Ural Branch of Russian Academy of Science, Issue 14 (in Russian).

Smolonogov E.P., 1968. Peculiarities of dynamics and structure of dark-coniferous forests of the northern-boreal Urals and adjacent part of the West-Siberian plain (Osobennosti dinamiki i stroeniya temnokhvoyno-kedrovykh lesov severnoy taigi Urala i prilegayuschey chasti Zapadno-Sibirskoy ravniny). In: Materials on dynamics of vegetation cover (Materialy po dinamike rastitel'nogo pokrova), Vladimir, pp. 39-40 (in Russian).

Smolonogov E.P., 1990. Ecological-geographical differentiation and dynamics of Siberian pine forests in Ural and Western-Siberian Plain ecological-forestry basics of optimization of forestry (Ekologogeograficheskaya differentsiatsia i dinamika kedrovikh lesov Urala i Zapadno-Sibirskoj ravniny: ekologo-lesovodstvennyje osnovy potimizatsii khozyajstva), Sverdlovsk (in Russian).

Smolonogov E.P., 1999. About a forest-forming process (O lesoobrazovatel'nom protsesse). Russian Forest Sciences (Lesovedenye) 3: 7-12 (in Russian).

Smolonogov E.P., 2000. Forest-forming process and windthrows (Lesoobrazovatel'niy protsess i vetrovaly). In: The consequences of catastrophic windthrow for forest ecosystems (Posledstviya katastroficheskogo vetrovala dlya lesnykh ecosystem), Alesenko Yu. M.v. (Ed.), Ekaterinburg, URO RAS, pp. 12-18 (in Russian).

Smolonogov E.P., Kirsanov V.A., and Trusov P.F., 1971. Peculiarities of age dynamics of dark-coniferous Siberian pine forests in Northern Ural (Osobennosti vozrastnoj dinamiki temnokhvojno-kedrovikh lesov Severnogo Urala). In: Use and renewal of Siberian pine forests (Ispol'zovaniye i vosproizvodstvo kedrovykh lesov), Krylov G.V. (Ed.), Novosibirsk, Nauka, pp. 73-81 (in Russian).

Sofronov M.A. and Volokitina A.V., 1990. Division of taiga zone into pyrological districts (Pirologicheskoye rajonirovaniye $\mathrm{v}$ tayezhnoj zone), Novosibirsk, Nauka, 205 p. (in Russian).

Sokolovsky V., 1908. The typological study of the forests of Arkhangelsk region according to the research data and personal observations (Tipologichesly ocherk lesov Arkhangel'skoy gubernii po dannym raznykh issledovaniy i po lichmym nabludeniyam). Forest Journal (Lesnoy Journal) 8: 985-1032 (in Russian).

Soloviev K.P. and Solodukhin E.D., 1953. Classification of burnt areas in the Far East (Klassifikatsya garej na Dalnem Vostoke). Forestry (Lesnoye khozyajstvo) No. 2 (in Russian).

Storozhenko V.G., 2004. Stable forest communities (Ustojchivyje lesnyje soobschestva). In: Fungal communities in forest ecosystems (Gribnyje soobschestva lesnykh ekosistem), Karelian Centre of Russian Academy of Sciences, vol. 2., pp. 52-60 (in Russian).

Storozhenko V.G., Bondartseva M.A., Soloviev V.A., and Krutov V.I., 1992. Scientific grounds of resilience of forests against wood decaying fungi (Nauchnyje osnovy ustojchivosti lesov k derevorazrushauschim gribam), Moskow, Nauka, 222 p. (in Russian).

Svalov N.N., 1961. The continuous forest use in primeval forests (Nepreryvnoye lesopol'zovanye v neosvoennykh lesakh). Forestry (Lesnoye Khozyaystvo) 12: 27-31 (in Russian).

Tikhonov A.S. and Zyabchenko S.S., 1990. Theory and practice of forest cuttings (Teorija i praktika rubok lesa), Petrozavodsk, Karelian Science Centre RAS, 224 p. (in Russian).

Timofeev N., 1894. About forests of the Far North (O lesakh kraynego Severa). Forest Journal (Lesnoy Journal) 1: 17-45 (in Russian).

Tkachenko M.E., 1931. Concentrated cuts, exploitation and forest regeneration (Kontsentrirovannye rubki, ekspluatatsiya i vozobnovleniye lesa), M. L., Sel'kolkhozgiz, 176 p. (in Russian).
Tolmachev A.I., 1954. History of origin and development of dark coniferous taiga ( $\mathrm{K}$ istoryii vozniknoveniya i razvitiya temnokhvoinoy taigi), M. L., RAS USSR, 156 p. (in Russian).

Turkov V.G., 1985. About uprooting in primeval forest as about biogeocoenotic phenomenon (O vyvale derev'ev v lesu vetrom kak o biogeotsenoticheskom yavlenii). In: Dark coniferous forests of Middle Ural (Temnokhvojnye lesa Srednego Urala), USC RAS pp. 121-140 (in Russian).

Ulanova N.G., 2000. The effects of windthrow on forests at different spatial scales: a review. For. Ecol. Manage. 135: 155-167.

Utkin A.I., 1965. Forests of Central Yakutiya (Lesa tsentral'noj Jakutii), M., Nauka, 208 p. (in Russian).

Utkin A.I., 1999. The 'Forest-forming process' - concept of Russian forest science ("Lesoobrazovatel'niy protsess" - kontseptsia Rossiyskogo lesovedeniya). Russian Forest Sciences (Lesovedeniye) 3: 13-23 (in Russian).

Utkin A.I., 1991. The forest-forming process from ecological point of view (Lesoobrazovatel'niy protsess s pozitsii ekologii). In: The theory of forest-forming process (Teoria lesoobrazovatel'nogo protsessa), Abstracts Int. Conf. Krasnoyarsk, pp. 161-162 (in Russian).

Valendik E.N. and Ivanova G.A., 2001. Fire regimes in the forests of Siberia and Far East (Pozharnye rezhimy v lesakh Sibiri i Dal'nego Vostoka). Russian Forest Sciences (Lesovedenye) 4: 69-76 (in Russian).

Valyaev V.N., 1961. The age structure of spruce forests of the Mezensky region (Vozrastnaya struktura el'nikov Mezenskogo rayona). Forest Journal (Lesnoy Journal) 5: 25-29 (in Russian).

Valyaev V.N., 1984. Selective and clear cuttings in Karelia, Petrozavodsk, 63 p. (in Russian).

Vargas de Bedemar, 1850. Studies of the growing stock and increment of forest stands in the Saint-Petersburg gubernya (Issledovanya zapasa i prirosta lesonasazhdeniy Sankt-Peterburgskoy gubernii), SPb, Vol'no-Economicheskoye Obschestvo (in Russian).

Vaschuk L.N. and Shvidenko A.Z., 2006. Dynamics of forests of Irkutsk region (Dinamika lesnykh prostranstv Irkutskoj oblasti), Irkutsk, 392 p. (in Russian).

Verkhunov P.M., 1970. Genesis and age structure of modern pine forests in Siberia (Genezis i vozrastnoye stroenije sovremennykh sosnovykh lesov Sibiri). Forestry research in the forests of Siberia (Lesovodstvennyje issledovanija v lesakh Sibiri) 2: 7-58 (in Russian).

Verkhunov P.M., 1979. The volume increment of uneven-aged pine forests (Prirost zapasa raznovozrastnykh sosnyakov), Novosibirsk, 248 p. (in Russian).

Volkov A.D., 2003. The bio-ecological basics of exploitation of spruce forests in the north-west of taiga zone of Russia (Bioekologicheskye osnovi ekspluatatsii el'nikov severo-zapada taezhnoy zony Rossii), Petrozavodsk, Karelian Science Centre of Russian Academy of Sciences, 250 p. (in Russian).

Voropanov P.V., 1950. The spruce forests in the North (El'niki Severa), M., L., Goslesbumizdat, 143 p. (in Russian).

Vygodskaya N.N., Abrazhko V.I., Varlagin A.V., Kurbatova Yu.A., Sidorov K.N., Milyukova I.M., Sogachev A.F., Sogacheva L.M., Shaposhnokov E.S., Nepomnyashchii G.I., and Abrazhko M.A., 2004. Long-term dynamics of soil moisture and drying of spruce trees in spruce forests of the southern taiga (Mnogoletnyaya dinamika pochvennogo uvlazhneniya $\mathrm{i}$ usykhaniye yeli $\mathrm{v}$ yelovikh lesakh evropeyskoj taigi). Russian Forest Sciences (Lesovedenye) 1: 3-22 (in Russian).

Yaroshenko A.Yu., Potapov P.V., and Turubanova S.A., 2001. The last intact forest landscapes of Northern European Russia, Green Peace Russia, 77 p.

Yashnov L.I., 1934. Cuttings of forest (Rubki lesa), Joshkar-Ola (in Russian).

Zyabchenko S.S., 1970. Improvement of cutting methods in pine forests in Karelia (Sovershenstvovanije sposobov rubok v sosnyakakh Karelii). Forestry (Lesnoye khozyajstvo) 5: 29-32 (in Russian).

Zyabchenko S.S., 1984. Pine forests of the European North (Sosnovye lesa evropeyskogo Severa), L., Nauka, 248 p. (in Russian). 